\title{
A Non-Fullerene Acceptor with Enhanced Intermolecular $\pi$-Core Interaction for High-Performance Organic Solar Cells
}

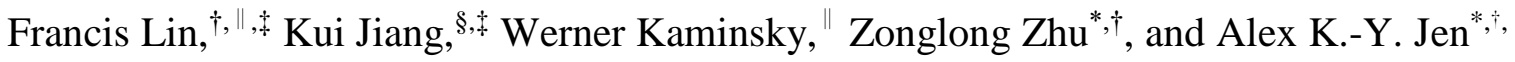
$\|, \S, \perp$

${ }^{\dagger}$ Department of Chemistry, City University of Hong Kong, Kowloon, Hong Kong

"Department of Chemistry, University of Washington, Seattle, Washington 98195-1700, United States

${ }^{\S}$ Department of Materials Science and Engineering, City University of Hong Kong, Kowloon, Hong Kong

${ }^{\perp}$ Department of Materials Science and Engineering, University of Washington, Seattle, Washington 98195-2120, United States

*E-mail: zonglzhu@cityu.edu.hk

*E-mail: alexjen@cityu.edu.hk

\section{Supporting Information}

\section{Table of Contents}

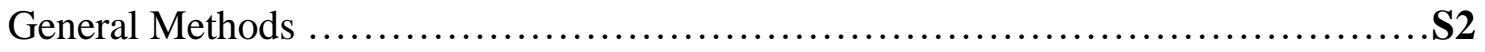

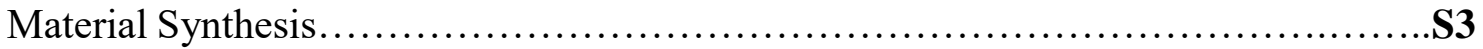

Optical and Electrochemical Characteristics ................................. S9

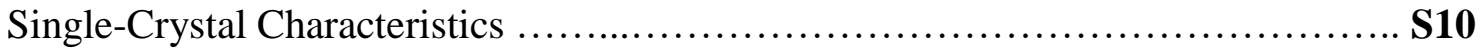

Photovoltaic and SCLC Device Characteristics ..............................S19

Light Intensity Dependence Characteristics ............................... S21

Atomic Force Microscopy Characteristics ................................... 22

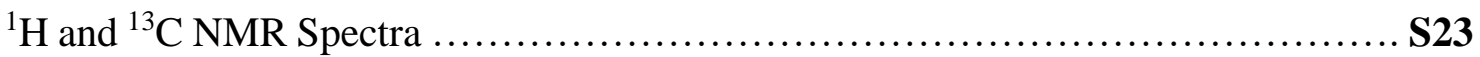

References.............................................................. S30 


\section{General Methods.}

Unless otherwise stated, all chemicals and reagents were used as received from commercial sources (Sigma-Aldrich, Acros, Matrix Scientific, Combi-Blocks) without further purification. Solvents for chemical synthesis were purified by distillation under nitrogen or by a solvent purification system (Innovative Technology). All chemical reactions were carried out under an argon or nitrogen atmosphere. Compound $\mathbf{1}$ and 2-butyloctyl iodide were prepared according to literature procedures. ${ }^{1-2}$ Polymeric donor PM6 was purchased from Solarmer Inc. Y6 was synthesized according to literature. ${ }^{3}$ The ${ }^{1} \mathrm{H}$ and ${ }^{13} \mathrm{C}$ NMR spectra were recorded on a Bruker AV500 spectrometer in $\mathrm{CDCl}_{3}, d_{6}$-DMSO or $\mathrm{C}_{6} \mathrm{D}_{6}$. Mass spectrometry was performed on Bruker APEX III 47e Fourier Transform mass spectrometer. The solution UV-Vis spectra were recorded on a Varian Cary 5000 UV-VisNIR Spectrophotometer. The film absorbance spectra were acquired on an Agilent 8454 Spectrophotometer UV-AG-3. All film samples were spin-cast on glass substrates. Cyclic voltammetry was conducted using a $\mathrm{CH}$ Instruments $\mathrm{CHI660E}$ Electrochemical Analyzer/Workstation with a conventional three-electrode cell with a glassy carbon working electrode, a Pt wire counter-electrode, and an $\mathrm{Ag} / \mathrm{AgCl}$ reference electrode at a scan rate of $50 \mathrm{mV} / \mathrm{s}$ using $0.1 \mathrm{M}$ tetrabutylammonium hexafluorophosphate $\left(\mathrm{TBAPF}_{6}\right)$ in $\mathrm{CHCl}_{3}$ as the electrolyte and referenced to the $\mathrm{FeCp}_{2} / \mathrm{FeCp}_{2}{ }^{+}$redox couple. 


\section{Material Synthesis.}

Preparation of $2 M$ solution of lithium diisopropylamide (LDA) in THF. A 3-neck roundbottom-flask was flame-dried under vacuum, cooled to room temperature, refilled with argon, and was added dry THF and diisopropylamine (1.05 eq, freshly distilled from $\mathrm{KOH}$ under nitrogen). The volume of THF was calculated to reach a reagent concentration of $c a$. $2 \mathrm{M}$. The mixture was cooled to $0{ }^{\circ} \mathrm{C}$, and $n-\mathrm{BuLi}$ (2.5 $\mathrm{M}$ in hexanes, $\left.1.00 \mathrm{eq}\right)$ was dropwise added to give a slightly cloudy solution with a pale color of yellow. The mixture was then stirred at $0{ }^{\circ} \mathrm{C}$ for $30 \mathrm{~min}$, then raised to room temperature and stirred for another $30 \mathrm{~min}$ to give the desired LDA solution, which was immediately used after cooled to appropriate temperature.
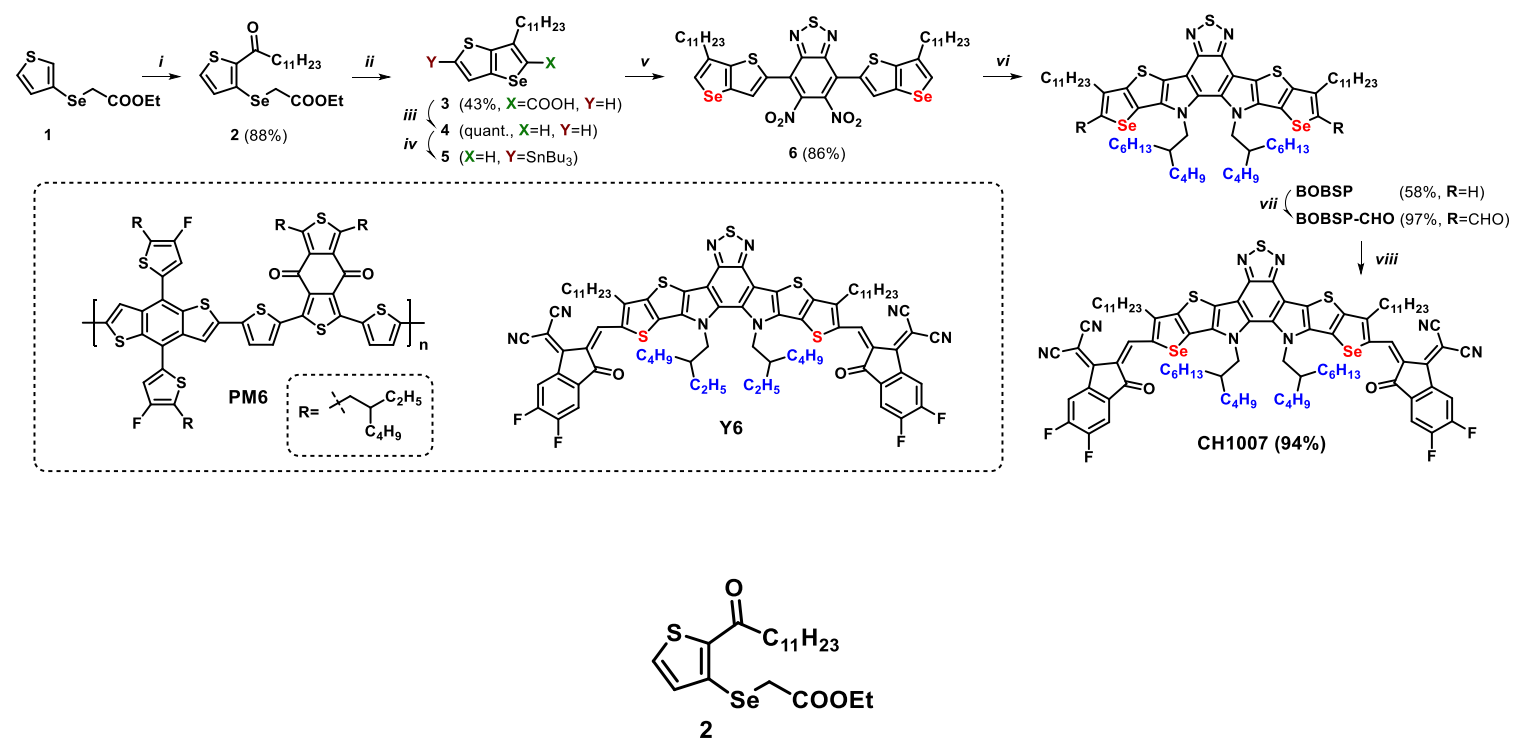

Synthesis of ethyl [2-(lauroylthiophen-3-yl)selanyl]acetate. (2) To a stirred solution of ethyl 2-(thiophen-3-ylselanyl)acetate $(1,15.0 \mathrm{~g}, 60.0 \mathrm{mmol})$ and lauroyl chloride $(15.3 \mathrm{~mL}$, $66.0 \mathrm{mmol})$ in dry toluene $(60 \mathrm{~mL})$ was dropwise added a solution of tin(IV) chloride (7.34 $\mathrm{mL}, 63.0 \mathrm{mmol})$ in dry toluene $(30 \mathrm{~mL})$ at $-10^{\circ} \mathrm{C}$. The mixture was kept at $-10{ }^{\circ} \mathrm{C}$ for 30 minutes, and then stirred at room temperature overnight. The reaction was quenched by addition of $10 \% \mathrm{HCl}$ in aqueous solution and extracted with $\mathrm{CH}_{2} \mathrm{Cl}_{2}$. The combined extracts were washed with brine, dried over anhydrous $\mathrm{MgSO}_{4}$, and then filtered. The solvent was removed by rotary evaporation to give the crude product as a brown oil, which was further purified by column chromatography on silica gel with hexanes/ $\mathrm{CH}_{2} \mathrm{Cl}_{2}(\mathrm{v} / \mathrm{v}=$ 2:1) as eluent to afford 2 as a yellow oil (22.7 g, 88\%), which slowly solidified under 
prolonged storage. ${ }^{1} \mathrm{H} \mathrm{NMR}\left(\mathrm{CDCl}_{3}, 500 \mathrm{MHz}\right) \delta 7.54(\mathrm{~d}, J=5.0 \mathrm{~Hz}, 1 \mathrm{H}), 7.35(\mathrm{~d}, J=5.0$ $\mathrm{Hz}, 1 \mathrm{H}), 4.16(\mathrm{q}, J=5.0 \mathrm{~Hz}, 2 \mathrm{H}), 3.56(\mathrm{~s}, 2 \mathrm{H}), 2.79(\mathrm{t}, J=5.0 \mathrm{~Hz}, 2 \mathrm{H}), 1.73$ (quintet, $J=$ $5.0 \mathrm{~Hz}, 2 \mathrm{H}), 1.35-1.22(\mathrm{~m}, 19 \mathrm{H}), 0.86(\mathrm{t}, J=5.0 \mathrm{~Hz}, 3 \mathrm{H}) ;{ }^{13} \mathrm{C} \mathrm{NMR}\left(\mathrm{CDCl}_{3}, 125 \mathrm{MHz}\right)$ $\delta$ 193.09, 171.06, 138.50, 132.21, 131.19, 128.71, 61.40, 40.52, 31.84, 29.54, 29.38, 29.34, 29.25, 29.24, 25.56, 24.60, 22.61, 14.03, 14.00; GC-MS (m/z) Calcd for $\mathrm{C}_{20} \mathrm{H}_{32} \mathrm{O}_{3} \mathrm{SSe}$ 432.12 , found 432.08 .
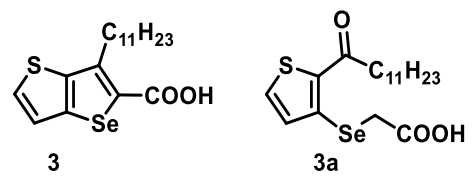

Synthesis of 6-undecylselenopheno[3,2-b]thiophene-5-carboxylic acid (3). At room temperature, a solution of $2(28.0 \mathrm{~g}, 65.0 \mathrm{mmol})$ in absolute ethanol $(65 \mathrm{~mL})$ was dropwise added into a solution of NaOEt, which was freshly prepared from sodium (4.48 g, 195 $\mathrm{mmol})$ and absolute ethanol $(130 \mathrm{~mL})$, under an argon atmosphere to form a thick yellow slurry. The mixture was then refluxed overnight, after which the solvents were removed by rotary evaporation. The residue was dissolved in water and acidified with $10 \% \mathrm{HCl}$ in aqueous solution, followed by extraction using ethyl acetate. The combined extracts were washed with brine, dried over anhydrous $\mathrm{MgSO}_{4}$, and then filtered. The solvent was removed by rotary evaporation to give the crude product as a brown solid, which was further purified by column chromatography on silica gel with $\mathrm{CH}_{2} \mathrm{Cl}_{2}$ as eluent to afford $\mathbf{3}$ as a white solid $(10.77 \mathrm{~g}, 43 \%) .{ }^{1} \mathrm{H}$ NMR $\left(d_{6}-\mathrm{DMSO}, 500 \mathrm{MHz}\right) \delta 7.84(\mathrm{~d}, J=5.0 \mathrm{~Hz}, 1 \mathrm{H})$, $7.52(\mathrm{~d}, J=5.0 \mathrm{~Hz}, 1 \mathrm{H}), 3.08(\mathrm{t}, J=5.0 \mathrm{~Hz}, 2 \mathrm{H}$ ), 1.64 (quintet, $J=5.0 \mathrm{~Hz}, 2 \mathrm{H}$ ), $1.31-1.21$ $(\mathrm{m}, 16 \mathrm{H}), 0.84(\mathrm{t}, J=5.0 \mathrm{~Hz}, 3 \mathrm{H}) ;{ }^{13} \mathrm{C}$ NMR $\left(d_{6}\right.$-DMSO, $\left.125 \mathrm{MHz}\right) \delta 164.88,143.91$, $142.67,139.65,131.70,130.65,124.12,31.24,29.71,28.94,28.85,28.82,28.65,28.64$, 22.05, 13.90.; GC-MS ( $\mathrm{m} / \mathrm{z}$ ) Calcd for $\mathrm{C}_{18} \mathrm{H}_{26} \mathrm{O}_{2} \mathrm{SSe} 386.08$, found 386.09. A portion of 2 hydrolyzed instead of forming the desired cyclized product during the reaction, giving [2(lauroylthiophen-3-yl)selanyl]acetic acid (3a), which was recovered using ethyl acetate/ $\mathrm{CH}_{2} \mathrm{Cl}_{2}$ (v/v = 1:3) as eluent, also as a white solid (10.22 g, 39\%). 


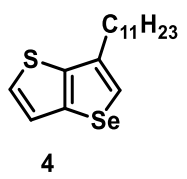

Synthesis of 6-undecylselenopheno[3,2-b]thiophene (4). A mixture of 3 (3.85 g, 10.0 $\mathrm{mmol})$ and silver carbonate $(110 \mathrm{mg}, 0.40 \mathrm{mmol})$ in DMSO $(15 \mathrm{~mL})$ was added acetic acid (46 $\mu \mathrm{L}, 0.80 \mathrm{mmol}$ ), and then heated at $120{ }^{\circ} \mathrm{C}$ overnight. The reaction mixture was then cooled to room temperature and passed through a celite pad to remove the inorganic residues. The celite pad was rinsed with diethyl ether for several times, and the combined filtrates were extracted with water. The combined extracts were washed with brine, dried over anhydrous $\mathrm{MgSO}_{4}$, and then filtered. The solvent was removed by rotary evaporation to give the crude product as a light brown oil, which was further purified by column chromatography on silica gel with hexanes as eluent to afford 4 as a colorless oil $(3.41 \mathrm{~g}$, quant.). ${ }^{1} \mathrm{H} \mathrm{NMR}\left(\mathrm{CDCl}_{3}, 500 \mathrm{MHz}\right) \delta 7.51(\mathrm{~s}, 1 \mathrm{H}), 7.33(\mathrm{~m}, 2 \mathrm{H}), 2.71(\mathrm{t}, J=5.0 \mathrm{~Hz}, 2 \mathrm{H})$, 1.77 (quintet, $J=5.0 \mathrm{~Hz}, 2 \mathrm{H}), 1.40-1.28(\mathrm{~m}, 16 \mathrm{H}), 0.90(\mathrm{t}, J=5.0 \mathrm{~Hz}, 3 \mathrm{H}) ;{ }^{13} \mathrm{C} \mathrm{NMR}$ $\left(\mathrm{CDCl}_{3}, 125 \mathrm{MHz}\right) \delta 141.93,137.28,136.95,125.95,123.89,123.00,31.91,31.56,29.65$, 29.62, 29.56, 29.40, 29.38, 29.33, 28.42, 22.68, 14.10; GC-MS (m/z) Calcd for $\mathrm{C}_{17} \mathrm{H}_{26} \mathrm{SSe}$ 342.09 , found 342.10 .

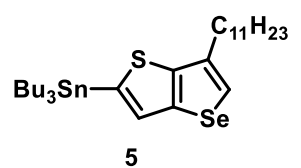

Synthesis of 6-undecyl-2-tributylstannylselenopheno[3,2-b]thiophene (5). To a stirred solution of 4 (3.41 g, $10.0 \mathrm{mmol})$ in dry THF (40 mL) was added LDA (11.0 mmol), which was freshly prepared from diisopropylamine $(1.63 \mathrm{~mL}, 11.6 \mathrm{mmol})$ and $n$-BuLi $(2.5 \mathrm{M}$ in hexanes, $4.40 \mathrm{~mL}, 11.0 \mathrm{mmol})$ in dry THF $(5.5 \mathrm{~mL})$, at $-40{ }^{\circ} \mathrm{C}$ (dry ice/ACN) under an argon atmosphere. After stirring at $-40{ }^{\circ} \mathrm{C}$ for 1 hour, tributyltin chloride $(3.26 \mathrm{~mL}, 12.0$ mmol) was added in one portion under $-40{ }^{\circ} \mathrm{C}$. The reaction mixture was slowly warmed to room temperature overnight, quenched by addition of water and extracted with hexanes. The combined extracts were washed with brine, dried over anhydrous $\mathrm{MgSO}_{4}$, and then filtered. The solvent was removed by rotary evaporation to give the stannylated compound 5 as a light yellow oil, which was used without further purification. 


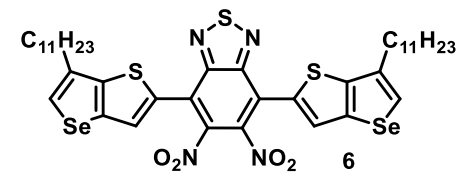

Synthesis of 5,6-dinitro-4,7-bis(6-undecylselenopheno[3,2-b]thiophen-2-yl)benzo[c][1,2,5]thiadiazole (6). A mixture of 5 (2.84 g, $4.50 \mathrm{mmol}$ ), 4,7-dibromo-5,6-dinitro[2,1,3] benzothiadiazole $(787 \mathrm{mg}, 2.05 \mathrm{mmol}), \mathrm{Pd}_{2}(\mathrm{dba})_{3}(18 \mathrm{mg}, 1 \mathrm{~mol} \%)$ and tri $(o-$ tolyl)phosphine $(49 \mathrm{mg}, 8 \mathrm{~mol} \%)$ in dry toluene $(10 \mathrm{~mL})$ was stirred under protection of argon at room temperature for 3 days. The solvents were then removed by rotary evaporation, and the residue was subjected onto a silica gel column then eluted with hexanes $/ \mathrm{CH}_{2} \mathrm{Cl}_{2}(\mathrm{v} / \mathrm{v}=4: 1)$ to afford 6 as a dark red solid $(1.60 \mathrm{~g}, 86 \%) .{ }^{1} \mathrm{H} \mathrm{NMR}\left(\mathrm{CDCl}_{3}\right.$, $500 \mathrm{MHz}) \delta 7.75(\mathrm{~s}, 2 \mathrm{H}), 7.71(\mathrm{~s}, 2 \mathrm{H}), 2.75(\mathrm{t}, J=5.0 \mathrm{~Hz}, 4 \mathrm{H}), 1.79$ (quintet, $J=5.0 \mathrm{~Hz}$, $4 \mathrm{H}), 1.42-1.27(\mathrm{~m}, 32 \mathrm{H}), 0.88(\mathrm{t}, J=5.0 \mathrm{~Hz}, 6 \mathrm{H}) ;{ }^{13} \mathrm{C} \mathrm{NMR}\left(\mathrm{CDCl}_{3}, 125 \mathrm{MHz}\right) \delta 152.20$, $146.69,141.70,137.80,137.09,129.55,127.84,127.07,121.13,31.90,31.41,29.65$, 29.62, 29.56, 29.38, 29.33, 28.38, 22.67, 14.09; MS (m/z, MALDI) Calcd for $\mathrm{C}_{40} \mathrm{H}_{50} \mathrm{~N}_{4} \mathrm{O}_{2} \mathrm{~S}_{3} \mathrm{Se}_{2}$ 906.13, found 906.09.

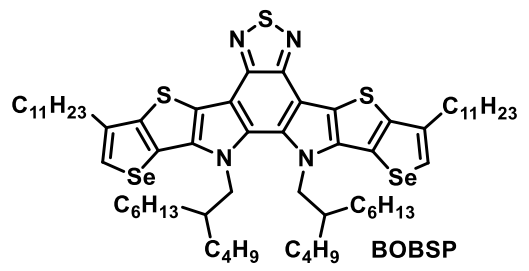

Synthesis of 12,13-bis(2-butyloctyl)-3,9-diundecyl-diselenopheno[2' ',3 ' ':4',5'] thieno[2', 3':4,5]pyrrolo[3,2-e:2',3'-g][2,1,3]benzothiadiazole (BOBSP). To a solution of 6 (723 $\mathrm{mg}, 0.80 \mathrm{mmol})$ in degassed 1,2-dicholorobenzene $(4 \mathrm{~mL})$ was added freshly distilled $\mathrm{P}(\mathrm{OEt})_{3}(2.74 \mathrm{~mL}, 16.0 \mathrm{mmol})$ under protection of argon. The reaction mixture was then refluxed overnight, cooled to room temperarture and precipitated with cold methanol. The crude product was collected by filtration as a bright orange solid, which was then dissolved in anhydrous DMF (16 mL) and added 2-butyloctyl iodide (1.42 g, $4.80 \mathrm{mmol})$ and freshly ground sodium hydroxide (256 mg, $6.40 \mathrm{mmol}$ ) under an argon atmosphere. The reaction mixture was then heated at $70{ }^{\circ} \mathrm{C}$ for 1 day, quenched by addition of water and extracted with $\mathrm{CH}_{2} \mathrm{Cl}_{2}$. The combined extracts were washed with brine, dried over anhydrous 
$\mathrm{MgSO}_{4}$, and then filtered. The solvent was removed by rotary evaporation to give the crude product as an orange oil, which was further purified by column chromatography on silica gel with hexanes/ $\mathrm{CH}_{2} \mathrm{Cl}_{2}(\mathrm{v} / \mathrm{v}=8: 1)$ as eluent to afford BOBSP as a yellowish orange solid (545 mg, $58 \%$ \%). ${ }^{1} \mathrm{H}$ NMR $\left(\mathrm{C}_{6} \mathrm{D}_{6}, 500 \mathrm{MHz}\right) \delta 7.15$ (s, 2H, overlapped with $\left.\mathrm{C}_{6} \mathrm{D}_{6}\right), 4.76$ (m, 4H), $2.63(\mathrm{t}, J=5.0 \mathrm{~Hz}, 4 \mathrm{H}), 2.28(\mathrm{~m}, 2 \mathrm{H}), 1.74(\mathrm{~m}, 4 \mathrm{H}), 1.31-1.29(\mathrm{~m}, 32 \mathrm{H}), 1.04-0.61$ $(\mathrm{m}, 50 \mathrm{H}) ;{ }^{13} \mathrm{C}$ NMR $\left(\mathrm{C}_{6} \mathrm{D}_{6}, 125 \mathrm{MHz}\right) \delta 148.31,144.44,139.15,132.86,123.45,122.36$, 112.52, 55.28, 39.23, 32.36, 32.03, 31.29, 30.13, 30.04, 29.84, 29.76, 29.06, 23.14, 22.90, 14.38, 14.27, 13.98; MS (m/z, MALDI) Calcd for $\mathrm{C}_{64} \mathrm{H}_{98} \mathrm{~N}_{4} \mathrm{~S}_{3} \mathrm{Se}_{2} 1178.53$, found 1178.32.

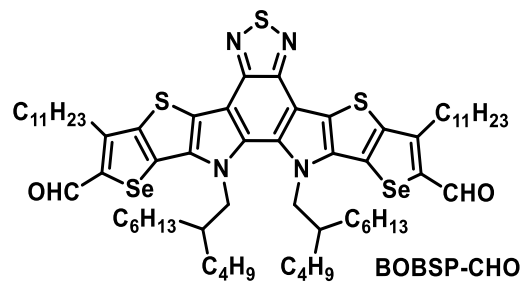

Synthesis of 12,13-bis(2-butyloctyl)-3,9-diundecyl-diselenopheno[2' ',3 ':4',5'] thieno[2', 3':4,5]pyrrolo[3,2-e:2',3'-g][2,1,3]benzothiadiazole-2,10-dicarbaldehyde

(BOBSPCHO). To a solution of BOBSP (471 mg, $0.40 \mathrm{mmol}$ ) in anhydrous 1,2-dichloroethane (12 $\mathrm{mL})$ was added anhydrous DMF $(496 \mu \mathrm{L}, 6.40 \mathrm{mmol})$ under the protection of argon. The reaction mixture was then cooled with an ice bath, followed by slow addition of $\mathrm{POCl}_{3}$ $(449 \mu \mathrm{L}, 4.80 \mathrm{mmol})$. After being kept at $0{ }^{\circ} \mathrm{C}$ for 10 minutes, the reaction mixture was heated at $80{ }^{\circ} \mathrm{C}$ overnight, cooled to room temperature, quenched with saturated aqueous solution of sodium acetate and extracted with $\mathrm{CH}_{2} \mathrm{Cl}_{2}$. The combined extracts were washed with brine, dried over anhydrous $\mathrm{MgSO}_{4}$, and then filtered. The solvent was removed by rotary evaporation to yield the crude product, which was then purified by column chromatography on silica gel with hexanes $/ \mathrm{CH}_{2} \mathrm{Cl}_{2}(\mathrm{v} / \mathrm{v}=4: 3)$ as eluent to afford BOBSPCHO as a reddish orange solid (480 mg, 97\%). ${ }^{1} \mathrm{H}$ NMR $\left(\mathrm{CDCl}_{3}, 500 \mathrm{MHz}\right) \delta 10.04$ (s, 2H), 4.59 (m, 4H), 3.19 (t, $J=5.0 \mathrm{~Hz}, 4 \mathrm{H}), 2.04$ (m, 2H), 1.93 (m, 4H), 1.31-1.29 (m, $32 \mathrm{H}), 1.04-0.61(\mathrm{~m}, 38 \mathrm{H}), 0.67-0.68(\mathrm{~m}, 12 \mathrm{H}) ;{ }^{13} \mathrm{C} \mathrm{NMR}\left(\mathrm{CDCl}_{3}, 125 \mathrm{MHz}\right) \delta 182.42$, $149.21,147.54,144.55,141.10,140.50,133.44,128.41,126.74,112.12,55.14,38.99$, $31.89,31.50,30.68,30.41,30.26,29.70,29.61,29.58,29.50,29.36,29.30,28.01,25.01$, 
22.73, 22.66, 22.42, 22.39, 14.08, 13.91, 13.69, 13.65; MS ( $\mathrm{m} / 2$, MALDI) Calcd for $\mathrm{C}_{66} \mathrm{H}_{98} \mathrm{~N}_{4} \mathrm{O}_{2} \mathrm{~S}_{3} \mathrm{Se}_{2}$ 1234.52, found 1234.64.

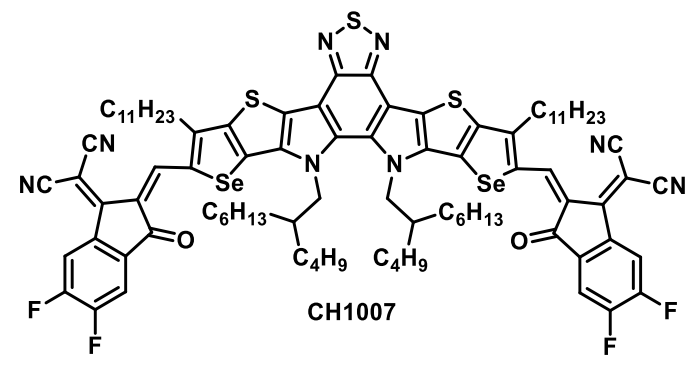

Synthesis of 2,10-bis(2-methylene-(3-(1,1-dicyanomethylene)-5,6-difluoroindanone))-12, 13-bis(2-butyloctyl)-3,9-diundecyl-diselenopheno[2 ', 3'”:4',5'] thieno [2 ',3':4,5] pyrrolo[3,2-e:2',3'-g][2,1,3]benzothiadiazole (CH1007). To a solution of BOBSP-CHO (222 $\mathrm{mg}, \quad 0.18 \mathrm{mmol}$ ) and 2-(5,6-difluoro-3-oxo-2,3-dihydro-1H-inden-1ylidene)malononitrile $(166 \mathrm{mg}, 0.72 \mathrm{mmol})$ in chloroform $(18 \mathrm{~mL})$ was added pyridine $(360 \mu \mathrm{L})$. The reaction mixture was then kept at room temperature until the completion of the reaction (ca. 1 day), after which the volatile species were removed by rotary evaporation. The crude product was then purified by column chromatography on silica gel with hexanes $/ \mathrm{CH}_{2} \mathrm{Cl}_{2}(\mathrm{v} / \mathrm{v}=4: 3)$ as eluent to afford $\mathbf{C H 1 0 0 7}$ as a black solid $(280 \mathrm{mg}$, 94\%). ${ }^{1} \mathrm{H} \mathrm{NMR}\left(\mathrm{CDCl}_{3}, 500 \mathrm{MHz}\right) \delta 9.24(\mathrm{~s}, 2 \mathrm{H}), 8.53$ (quartet, $\left.J=5.0 \mathrm{~Hz}, 2 \mathrm{H}\right), 7.70(\mathrm{t}$, $J=5.0 \mathrm{~Hz}, 2 \mathrm{H}), 4.72(\mathrm{~m}, 4 \mathrm{H}), 3.23(\mathrm{t}, J=5.0 \mathrm{~Hz}, 4 \mathrm{H}), 2.19(\mathrm{~m}, 2 \mathrm{H}), 1.85(\mathrm{~m}, 4 \mathrm{H}), 1.52$ $(\mathrm{m}, 4 \mathrm{H}), 1.36-0.85(\mathrm{~m}, 66 \mathrm{H}), 0.71-0.64(\mathrm{~m}, 12 \mathrm{H}) ;{ }^{13} \mathrm{C} \mathrm{NMR}\left(\mathrm{CDCl}_{3}, 125 \mathrm{MHz}\right) \delta 186.86$, 158.59, 156.87, 155.37, 153.29, 147.53, 147.42, 141.91, 137.76, 137.62, 136.52, 134.33, 134.08, 130.00, 119.14, 114.92, 114.53, 113.56, 112.36, 68.61, 55.78, 39.02, 31.90, 31.57, $31.53,31.30,30.45,30.36,29.92,29.64,29.61,29.50,29.47,29.33,28.04,27.89,25.45$, 25.30, 22.78, 22.74, 22.67, 22.45, 14.09, 13.98, 13.74, 13.71; MS (m/z, MALDI) Calcd for $\mathrm{C}_{90} \mathrm{H}_{102} \mathrm{~F}_{4} \mathrm{~N}_{8} \mathrm{O}_{2} \mathrm{~S}_{3} \mathrm{Se}_{2}$ 1658.56, found 1658.95 . 


\section{Optical and Electrochemical Characteristics.}

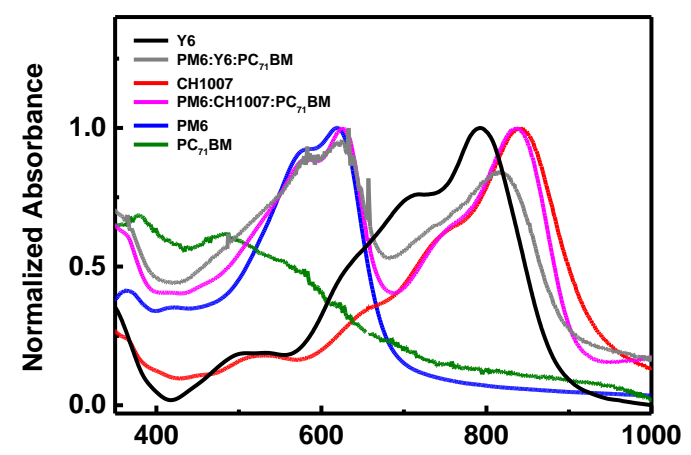

Figure S1. Thin-film absorption profiles of neat materials and blends.

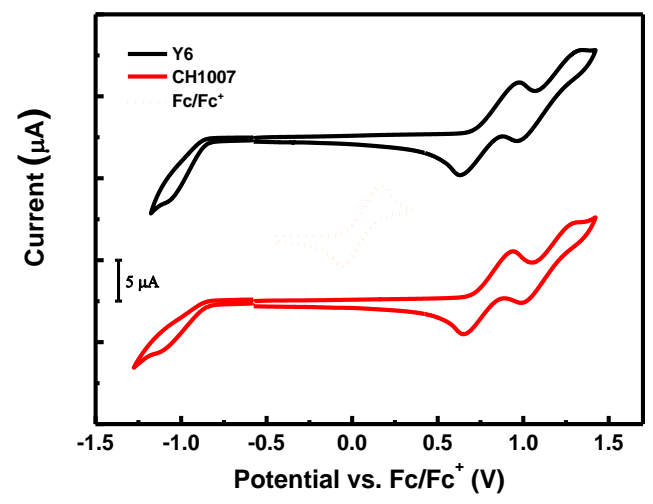

Figure S2. Cyclic voltammograms of Y6 and CH1007.

Table S1. Summary of optical and electrochemical characerisrtics of Y6 and CH1007.

\begin{tabular}{|c|c|c|c|c|c|c|c|c|c|}
\hline & $\begin{array}{c}\lambda_{\max , \text { soln }}{ }^{a} \\
(\mathrm{~nm})\end{array}$ & $\begin{array}{c}\varepsilon^{a} \\
\left(10^{4} \mathrm{~L} \mathrm{~mol}^{-1} \mathrm{~cm}^{-1}\right)\end{array}$ & $\begin{array}{c}\lambda_{\max , \text { film }}{ }^{b} \\
(\mathrm{~nm})\end{array}$ & $\begin{array}{l}\lambda_{\text {edge }}{ }^{c} \\
(\mathrm{~nm})\end{array}$ & $\begin{array}{l}\mathrm{E}_{\mathrm{g}, \text { film }}{ }^{d} \\
(\mathrm{eV})\end{array}$ & $\begin{array}{l}\mathrm{IP}^{e} \\
(\mathrm{eV})\end{array}$ & $\begin{array}{l}\mathrm{EA}^{e} \\
(\mathrm{eV})\end{array}$ & $\begin{array}{c}E_{g, c v^{f}} \\
(e V)\end{array}$ & $\begin{array}{c}\mu_{\mathrm{e}}^{g} \\
\left(\mathrm{~cm}^{2} \mathrm{~V}^{-1} \mathrm{~S}^{-1}\right) \\
\end{array}$ \\
\hline Y6 & 728 & 18.2 & 792 & 893 & 1.39 & -5.60 & -3.94 & 1.66 & $7.3 \times 10^{-5}$ \\
\hline CH1007 & 749 & 20.5 & 844 & 954 & 1.30 & -5.59 & -3.97 & 1.62 & $1.1 \times 10^{-4}$ \\
\hline \multicolumn{10}{|c|}{$\begin{array}{l}{ }^{a} \text { Measured in } \mathrm{CH}_{2} \mathrm{Cl}_{2} \text { solution }\left(1 \times 10^{-6} \mathrm{M}\right) .{ }^{b} \text { Spin-cast thin film. }{ }^{c} \text { Optical bandgap estimated from thin-film absorption. }{ }^{d} \mathrm{Calculate} \\
\text { from the absorption edge of thin-film spectra. }{ }^{e} \text { Cyclic voltammetry }(\mathrm{CV}) \text { was measured in } \mathrm{CHCl}_{3} \text { solution with } 0.1 \mathrm{M} \mathrm{NBu}_{4} \mathrm{PF}_{6} \mathrm{a} \\
\text { supporting electrolyte. Sample concentration was } 0.01 \mathrm{M} \text { for the measurements. All potentials were recorded using } \mathrm{Fc} / \mathrm{Fc}^{+} \text {as an externa } \\
\text { reference, which was referenced at }-4.80 \mathrm{eV} \text { below vacuum level. }{ }^{f} \text { Electrochemical bandgap estimated from the redox half potentials o } \\
\mathrm{CV} \text { measurement. }{ }^{g} \text { Please refer to } \mathrm{S17-18} \text { and Figure } \mathbf{S 5} \text { for details regarding electron mobility measurement. }\end{array}$} \\
\hline
\end{tabular}




\section{Single-Crystal Characteristics.}

Single-crystal growth - ternary solvent diffusion. A solution prepared from $~ 1 \mathrm{mg}$ NFA in $0.3 \mathrm{~mL} \mathrm{CHCl}_{3}$ was transferred into an $\mathrm{NMR}$ tube. Around $0.2 \mathrm{~mL}$ of $\mathrm{CH}_{2} \mathrm{Cl}_{2}$ was carefully layered on top of the $\mathrm{CHCl}_{3}$ solution, followed by carefully layering acetone or hexanes on top. The $\mathrm{CH}_{2} \mathrm{Cl}_{2}$ portion plays an important role as a buffer layer to create a gradient of solubility, which facilitates slow growth of crystals and suppresses the rapid precipitation of solids . The NMR tube was then sealed and left standing for a few days (3-7 days) until the color of the solution faded away. Y6, CH1007 and IT-4F were grown using this method.

Single-crystal growth - vapor diffusion. This method was used for growing crystals of NFAs based on linear $\pi$-cores. A solution prepared from $\sim 1 \mathrm{mg}$ NFA in $\sim 0.5 \mathrm{~mL}$ toluene or $\mathrm{CHCl}_{3}$ was transferred into a $4 \mathrm{~mL}$ vial, which was capped with a piece of aluminum foil with a hole punched using a $24 \mathrm{G}$ needle in the middle. The $4 \mathrm{~mL}$ vial was then placed in a $20 \mathrm{~mL}$ vial containing $\sim 3 \mathrm{~mL} \mathrm{CH}_{3} \mathrm{CN}$, acetone or $\mathrm{MeOH}$. The $20 \mathrm{~mL}$ vial was then tightly sealed, and left standing for a few days (2-4 days) to give small crystal clusters. ITIC, 4TIC, STIC and 6TIC-4F were grown using this method.

Single-crystal X-ray diffraction of Y6. A black lustrous prism with a bronze colored shimmer, measuring $0.40 \times 0.20 \times 0.07 \mathrm{~mm}^{3}$ was mounted on a loop with oil. Data was collected at $-173{ }^{\circ} \mathrm{C}$ on a Bruker APEX II single-crystal X-ray diffractometer, Moradiation. The crystals were stable under oil for only 5 minutes. Crystal-to-detector distance was $40 \mathrm{~mm}$ and exposure time was 120 seconds per frame for all sets. The scan width was $0.5^{\circ}$. Data collection was $99.1 \%$ complete to $25^{\circ}$ in $\vartheta$. A total of 29810 reflections were collected covering the indices, $-28<=\mathrm{h}<=28,-68<=\mathrm{k}<=68,-17<=1<=17$, with $\mathrm{R}_{\text {int }}=0.2471$. Indexing and unit cell refinement indicated a $\mathrm{C}$-centered monoclinic lattice. The space group was found to be C2/c (No.15).

Single-crystal X-ray diffraction of $\boldsymbol{C H 1 0 0 7}$. A black piece, measuring $0.11 \times 0.15$ x 0.32 $\mathrm{mm}^{3}$ was mounted on a loop with oil. Data was collected at $-173{ }^{\circ} \mathrm{C}$ on a Bruker APEX II single-crystal X-ray diffractometer, Mo-radiation. Crystal-to-detector distance was $40 \mathrm{~mm}$ 
and exposure time was 60 seconds per frame for all sets. The scan width was $1^{\circ}$. Data collection was $94.3 \%$ complete to $25^{\circ}$ in $\vartheta$. A total of 31724 unique reflections were collected covering the indices, $-13<=\mathrm{h}<=13,-22<=\mathrm{k}<=22,-30<=1<=30$, with $\mathrm{R}_{\text {int }}=0.2200$. Indexing and unit cell refinement indicated a triclinic lattice. The space group was found to be $\mathrm{P} \overline{1}$ (No. 2). 
Table S2. Crystallographic data for Y6.

Empirical formula

Formula weight

Temperature

Wavelength

Crystal system

Space group

Unit cell dimensions

Volume

Z

Density (calculated)

Absorption coefficient

$\mathrm{F}(000)$

Crystal size

Theta range for data collection

Index ranges

Reflections collected

Independent reflections

Completeness to theta $=25.000^{\circ}$

Refinement method

Data / restraints / parameters

Goodness-of-fit on $\mathrm{F}^{2}$

Final R indices [I $>2 \operatorname{sigma}(\mathrm{I})]$

$\mathrm{R}$ indices (all data)

Largest diff. peak and hole
$\mathrm{C}_{82} \mathrm{H}_{86} \mathrm{~F}_{4} \mathrm{~N}_{8} \mathrm{O}_{2} \mathrm{~S}_{5}$

1451.88

100(2) K

$0.71073 \AA$

Monoclinic

C $2 / \mathrm{c}$

$$
\begin{array}{ll}
\mathrm{a}=23.7019(19) \AA & \alpha=90^{\circ} . \\
\mathrm{b}=57.450(4) \AA & \beta=118.541(4)^{\circ} . \\
\mathrm{c}=14.3969(10) \AA & \gamma=90^{\circ} .
\end{array}
$$

17222(2) $\AA^{3}$

8

$1.120 \mathrm{Mg} / \mathrm{m}^{3}$

$0.190 \mathrm{~mm}^{-1}$

6128

$0.400 \times 0.200 \times 0.070 \mathrm{~mm}^{3}$

1.418 to $25.027^{\circ}$.

$-28<=\mathrm{h}<=28,-68<=\mathrm{k}<=68,-17<=\mathrm{l}<=17$

29810

$15085[\mathrm{R}(\mathrm{int})=0.2471]$

$99.1 \%$

Full-matrix least-squares on $\mathrm{F}^{2}$

15085 / 1543 / 1111

1.088

$\mathrm{R} 1=0.1770, \mathrm{wR} 2=0.4202$

$\mathrm{R} 1=0.4205, \mathrm{wR} 2=0.5272$

0.373 and -0.369 e. $\AA^{-3}$ 
Table S3. Crystallographic data for CH1007.

Empirical formula

Formula weight

Temperature

Wavelength

Crystal system

Space group

Unit cell dimensions

Volume

Z

Density (calculated)

Absorption coefficient

$\mathrm{F}(000)$

Crystal size

Theta range for data collection

Index ranges

Reflections collected

Independent reflections

Completeness to theta $=25.000^{\circ}$

Refinement method

Data / restraints / parameters

Goodness-of-fit on $\mathrm{F}^{2}$

Final R indices [I $>2 \operatorname{sigma}(\mathrm{I})]$

$\mathrm{R}$ indices (all data)

Largest diff. peak and hole
$\mathrm{C}_{90} \mathrm{H}_{102} \mathrm{~F}_{4} \mathrm{~N}_{8} \mathrm{O}_{2} \mathrm{~S}_{3} \mathrm{Se}_{2}$

1657.89

100(2) K

$0.71073 \AA$

Triclinic

\section{P -1}

$$
\begin{array}{ll}
\mathrm{a}=13.6204(13) \AA & \alpha=70.177(7)^{\circ} . \\
\mathrm{b}=23.304(3) \AA & \beta=83.982(6)^{\circ} . \\
\mathrm{c}=31.303(3) \AA & \gamma=80.737(6)^{\circ} .
\end{array}
$$

9211.8(18) $\AA^{3}$

4

\section{$1.195 \mathrm{Mg} / \mathrm{m}^{3}$}

$0.927 \mathrm{~mm}^{-1}$

3464

$0.320 \times 0.150 \times 0.110 \mathrm{~mm}^{3}$

1.385 to $25.821^{\circ}$.

$-13<=\mathrm{h}<=13,-22<=\mathrm{k}<=22,-30<=\mathrm{l}<=30$

31724

$31724[\mathrm{R}($ int $)=0.2200]$

$94.3 \%$

Full-matrix least-squares on $\mathrm{F}^{2}$

31724 / 2768 / 1951

1.300

$\mathrm{R} 1=0.2238, \mathrm{wR} 2=0.4797$

$\mathrm{R} 1=0.4724, \mathrm{wR} 2=0.5791$

1.526 and -0.808 e. $\AA^{-3}$ 
(a)

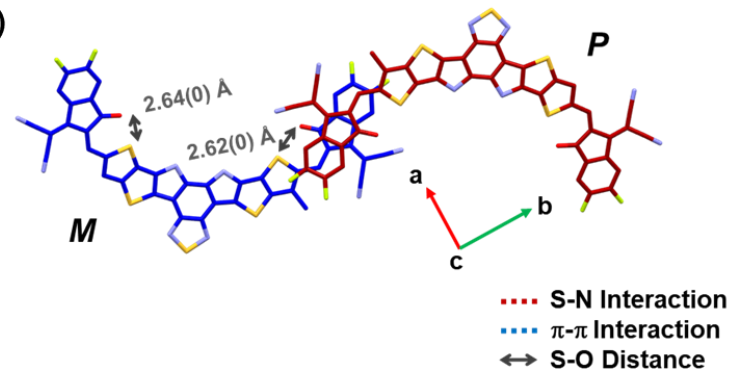

(c)

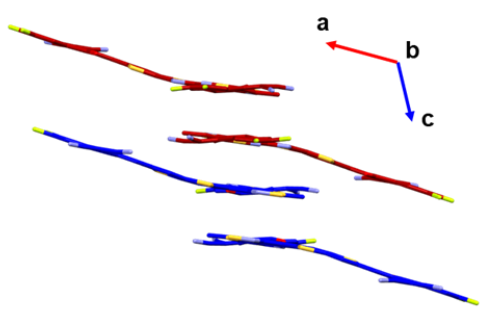

(b)

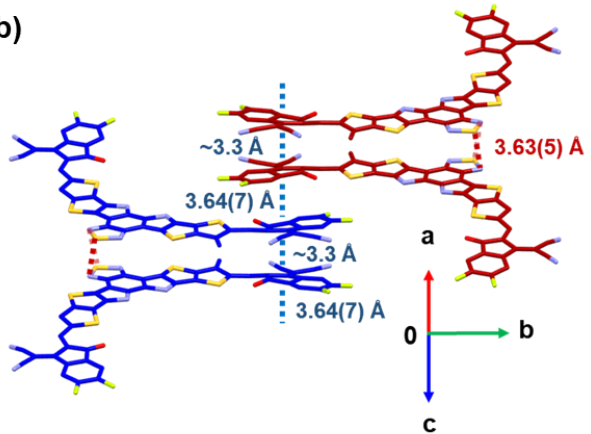

(d) $\mathrm{CH} 1007$

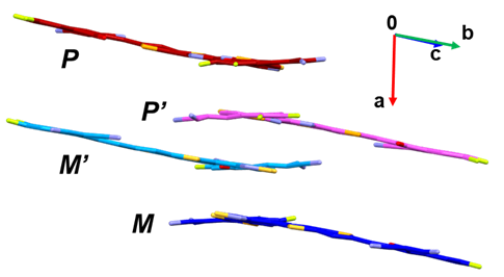

(e)

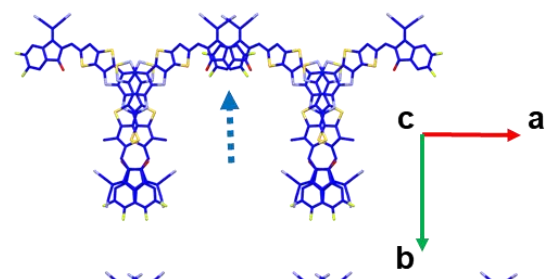

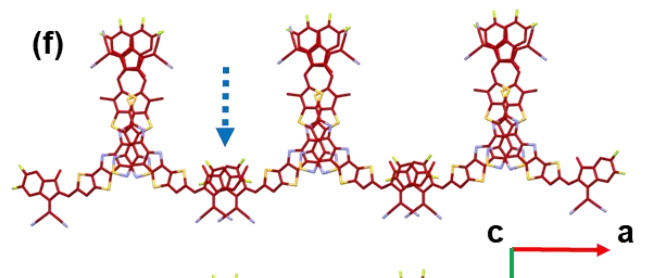
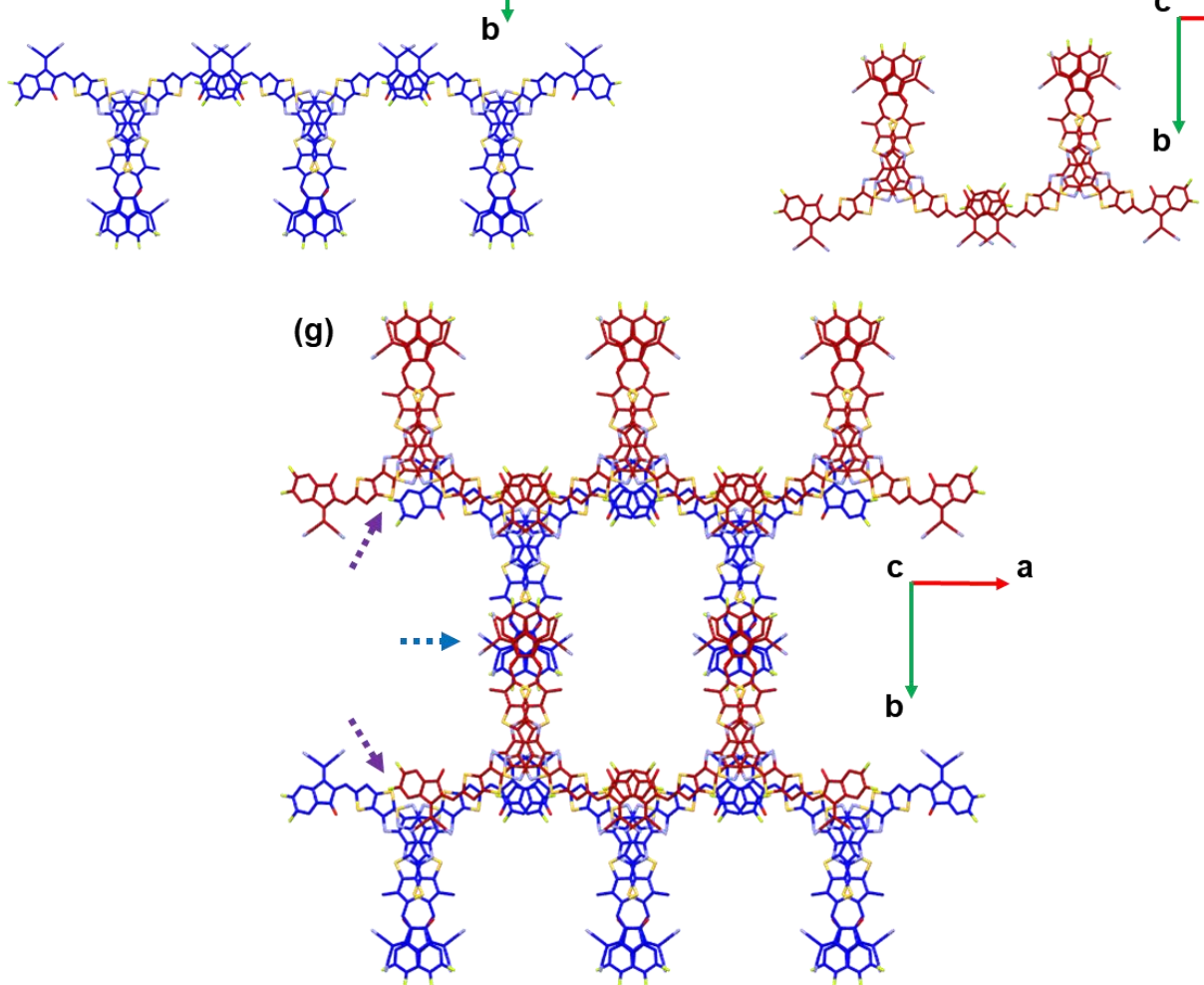

Figure S3. (a) $M$-enantiomer (carbons marked in blue) and $P$-enantiomer (carbons marked in brick red) of Y6. Two sets of D-A dihedral angles on different sides of Y6, which are 
$11.9(7)^{\circ}$ and $4.3(8)^{\circ}$, corresponding to different S-O distances of 2.62(0) $\AA$ and 2.64(0) $\AA$, were respectively measured. (b) Stacking of two pairs of Y6 enatiomers, showing (1) $\pi-\pi$ stacking between terminal groups with a $\pi$-distance of $c a .3 .3 \AA$, and (2) face-to-face $\pi$ core interaction between BT moieties through a pair of S-N interactions, with an S-N distance of 3.63(5) $\AA$. (c) Viewing the enatiomeric Y6 dimers along $b$-axis, showing the twisted structure of Y6. (d) Viewing the unit cell of CH1007 from a similar angle with (c), showing less torsion in the structure of $\mathbf{C H 1 0 0 7}$. (e-f) Comb-shape channel formed by (e) $M$ - and (f) $P$-enantiomers of Y6. The blue dashed arrows indicate stacking between terminal groups with a $\pi$-distance of $c a$. $3.5 \AA$. (g) 3D network in single-crystal of Y6. The dark violet dashed arrow indicates S-F interaction between $M$ - and $P$-channels, corresponding to a distance of 3.28(5) $\AA$, and the blue dashed arrows indicate intercalation of channels through $\pi-\pi$ stacking of terminal groups, corresponding to a $\pi$-distance of 3.64(7) $\AA$. The alkyl chains and hydrogen atoms are omitted for clarity.

Two videos of the enatiomeric dimers of Y6 and $\mathbf{C H 1 0 0 7}$ rotating along $b$-axis are provided in the supporting files.

A comparison of intermolecular interactions observed in NFAs based on linear $\pi$-cores from literature, or from unpublished data in our group, was also provided as in Table S4 and Figure S4. Although Yi et al. were the first single-crystal of ITIC, ${ }^{4}$ we were not able to retrieve the CIF file corresponding to this work. Marks et al. also published several works on single-crystal analysis of ITIC and its derivatives with terminal group modifications, ${ }^{5-6}$ suggesting that the size and electron-accepting strength of terminal groups attribute to molecular packing and charge transporting properties. Aside from the ITIC derivatives, our group has carried out multiple works on single-crystal structures of NFAs based on $\pi$-extended cyclopentadithiophenes. ${ }^{7-9}$ From these studies, one can tell that the $1^{\text {st }}$-generation NFAs based on 3-(dicyanomethylidene)indan-1-one terminal group (Table S4, ITIC, 4TIC, STIC) possess only marginal intermolecular interactions. Moreover, the co-existence of terminal group interactions and $\pi$-core interactions was not observed. The lack of intermolecular interactions could give arise to disordered molecular packing and undermine the charge transporting properties. 
The structural modification of terminal groups has led us to the $\mathbf{2}^{\text {nd }}$-generation NFAs (Table S4, 6TIC-4F, IT-4F). Terminal group interactions and $\pi$-core interactions have both been enhanced, and the fluorinated indanone terminal groups are capable of forming efficient intermolecular communication through $\pi$ - $\pi$ stacking, which extends to form a linear, polymer-like channel with conjugated backbone to serve as a pathway for charge transporting between different NFA molecules. The linear ladder-type $\pi$-cores in NFAs, however, are still isolated and only possess marginal edge-to-edge S-S interactions with each other due to the introduction of bulky, alkylated phenyl side chains onto their tertiary carbons (Table S4).

Y6 and CH1007 can be categorized as the $3^{\text {rd }}$-generation NFAs, possessing not only terminal group interactions but improved $\pi$-core interactions. 
Table S4. Intermolecular interactions in NFAs based on linear $\pi$-cores.

\begin{tabular}{|c|c|c|c|}
\hline & Terminal Group Interactions & $\pi$-Core Interactions & \\
\hline ITIC $^{a}$ & $\mathrm{X}$ & Edge-to-edge S-S interaction $(3.42(0) \AA)$ & Figure S4 (a) \\
\hline ITIC $^{5}$ & $\mathrm{X}$ & $\mathrm{X}$ & - \\
\hline $4 \mathrm{TIC}^{7}$ & $\pi-\pi$ Stacking & $\mathrm{X}$ & - \\
\hline STIC $^{9}$ & Partial overlapping & $\mathrm{X}$ & - \\
\hline $6 \mathrm{TIC}-4 \mathrm{~F}^{8}$ & Partial overlapping & Edge-to-edge S-S interaction (3.62(1) $\AA$ ) & Figure S4 (b) \\
\hline IT-4F $\mathbf{F}^{a}$ & $\pi-\pi$ Stacking & Edge-to-edge S-S interaction $(3.69(1) \AA ̊$ & Figure S4 (c) \\
\hline IT-4F $\mathbf{F}^{5}$ & $\mathrm{X}$ & Edge-to-edge S-S interaction (3.70(7) Å) & - \\
\hline
\end{tabular}

${ }^{a}$ Unpublished single-crystal data of ITIC and IT-4F were independently retrieved by our group. CCDC identification numbers: ITIC: 1579467; IT-4F: 2009658.

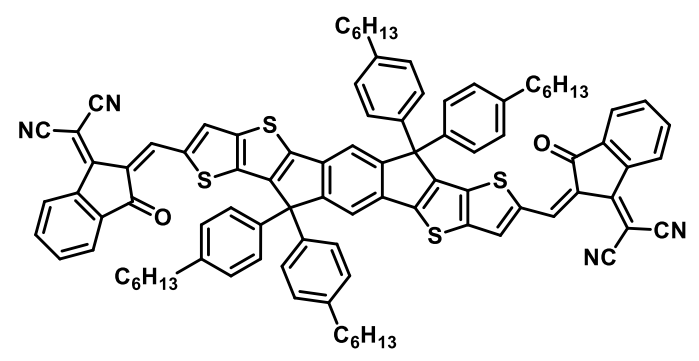

ITIC

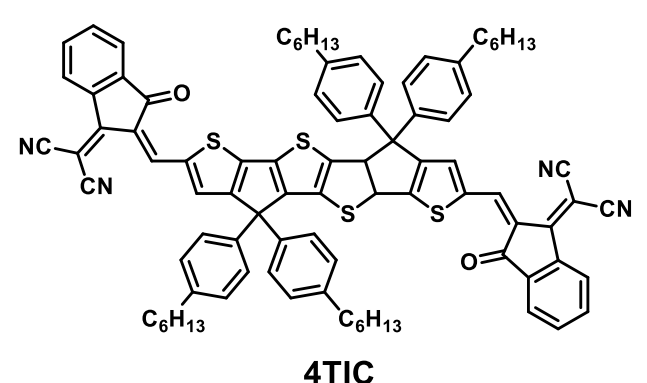

4TIC

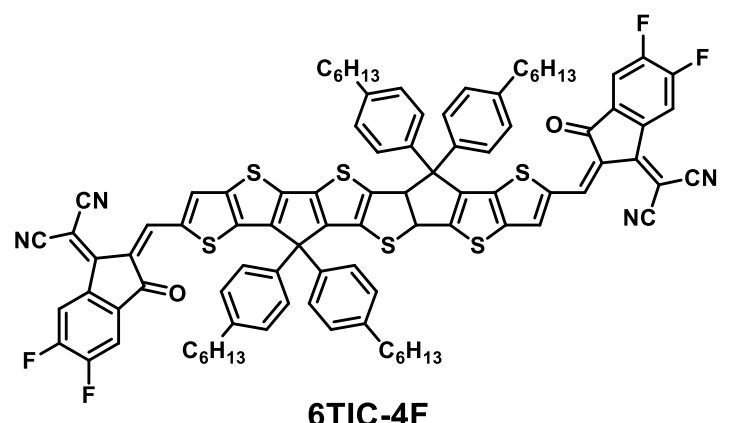

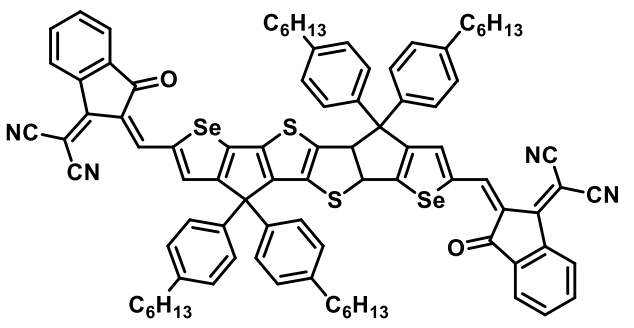

STIC

Figure S4. Chemical structures of ITIC, 4TIC, STIC, 6TIC-4F and IT-4F. 
(a) ITIC

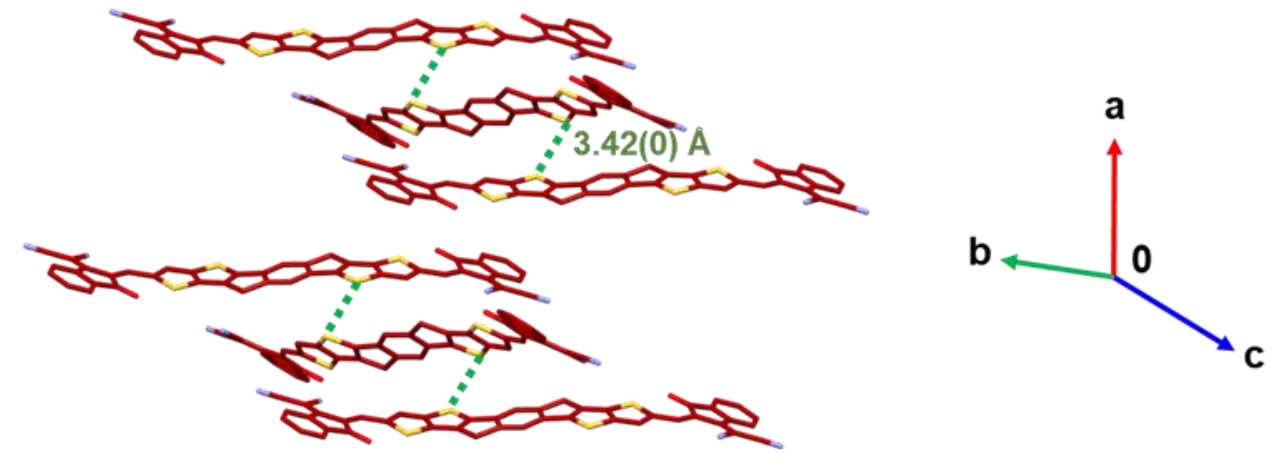

(b) $6 \mathrm{TIC}-4 \mathrm{~F}$
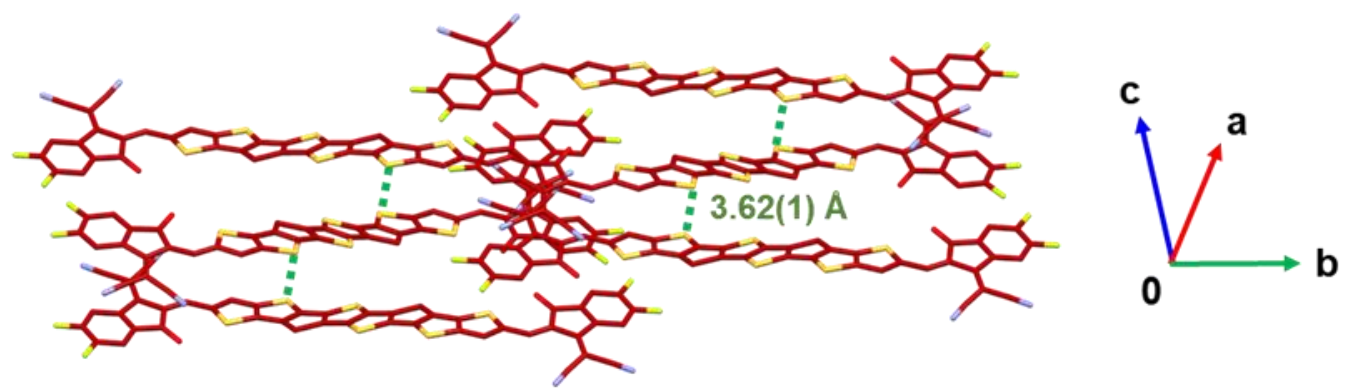

(c) IT-4Fa
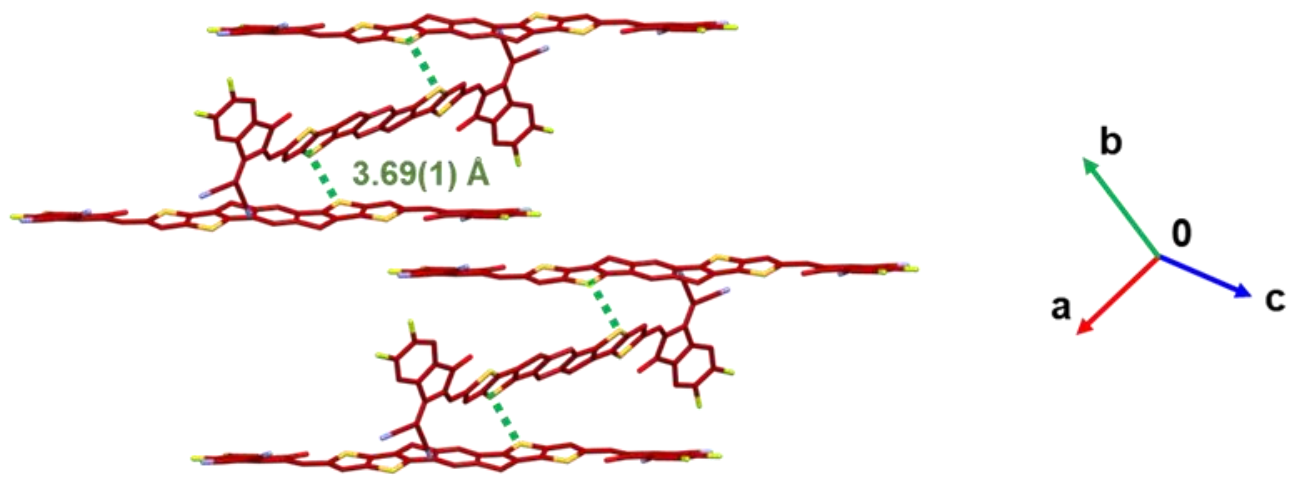

Figure S5. Single-crystal structures demonstrating edge-to-edge S-S interaction in (a) ITIC, ${ }^{a}$ (b) 6 TIC-4F, ${ }^{8}$ and (c) IT-4F. ${ }^{a}$ The alkyl chains and hydrogen atoms are omitted for clarity. ( ${ }^{a}$ Unpublished single-crystal data of ITIC and IT-4F were independently retrieved by our group. CCDC identification numbers: ITIC: 1579467; IT-4F: 2009658.) 


\section{Photovoltaic Device and SCLC Characteristics.}

Photovoltaic device fabrication and characterization. Solar cells were fabricated in a conventional device configuration of ITO/PEDOT:PSS/active layers/PNDIT-F3N/Ag. The ITO substrates were first scrubbed by detergent and then sonicated with deionized water, acetone and isopropanol subsequently, and dried overnight in an oven. The glass substrates were treated by plasma for 30 min before use. PEDOT:PSS (Heraeus Clevios P VP AI 4083) was spin-cast onto the ITO substrates at $5000 \mathrm{rpm}$ for $25 \mathrm{~s}$, and then dried at $150{ }^{\circ} \mathrm{C}$ for $15 \mathrm{~min}$ in air. The PM6:Y6/CH1007: $\mathrm{PC}_{71} \mathrm{BM}$ blends (1:0.96:0.24 weight ratio) or PM6:Y6/CH1007 blends (1:1.2 weight ratio) were dissolved in chloroform (the total concentration of blend solutions were $17.6 \mathrm{mg} \mathrm{mL}^{-1}$ for all blends), with the addition of $0.5 \% \mathrm{CN}$ as additive, and stirred for 2 hours on a hot plate at $55^{\circ} \mathrm{C}$ in a nitrogen filled glove box. The blend solution were spin-cast at 2000-3000 rpm for $39 \mathrm{~s}$ on the top of PEDOT:PSS layer followed by a thermal annealing step at $90{ }^{\circ} \mathrm{C}$ for $5 \mathrm{~min}$. A thin PNDIT-F3N layer was coated on the active layer, followed by the deposition of $\mathrm{Ag}(90 \mathrm{~nm})$ (evaporated under $2 \times 10^{-6}$ mbar through a shadow mask). The optimal active layer thickness measured by a Bruker Dektak XT stylus profilometer was about $100 \mathrm{~nm}$. The current density-voltage $(J-$ $V)$ curves of all encapsulated devices were measured using a Keithley 2400 Source Meter in $\mathrm{N}_{2}$-filled glovebox under AM 1.5G $\left(100 \mathrm{~mW} \mathrm{~cm}^{-2}\right)$ by a solar simulator (Enlitech, SSF5, Taiwan). The light intensity was calibrated using a standard Si diode (calibrated in National Renewable Energy laboratory with a KG5 filter). A mask aperture area of 0.04 $\mathrm{cm}^{2}$ was used during $J-V$ measurement. EQEs were measured using an Enlitech QE-S EQE system equipped with a standard Si diode.

SCLC device fabrication and characterization. The hole-only and electron-only devices were fabricated by employing the following device structure: ITO/ $\mathrm{MoO}_{3} / \mathrm{blend}$ film/ $/ \mathrm{MoO}_{3} / \mathrm{Al}$ for holes and ITO/ZnO/blend film/PNDIT-F3N/Al for electrons. The mobilities were obtained by taking current-voltage curves and fitting the results to the equation listed below:

$$
J=\frac{9 \varepsilon_{0} \varepsilon_{r} \mu V^{2}}{8 L^{3}}
$$


where $J$ is the current density, $\varepsilon_{0}$ is the vacuum permittivity, $\varepsilon_{r}$ is the relative dielectric constant, $\mu$ is the mobility, $V$ is the voltage, and $L$ is the film thickness.
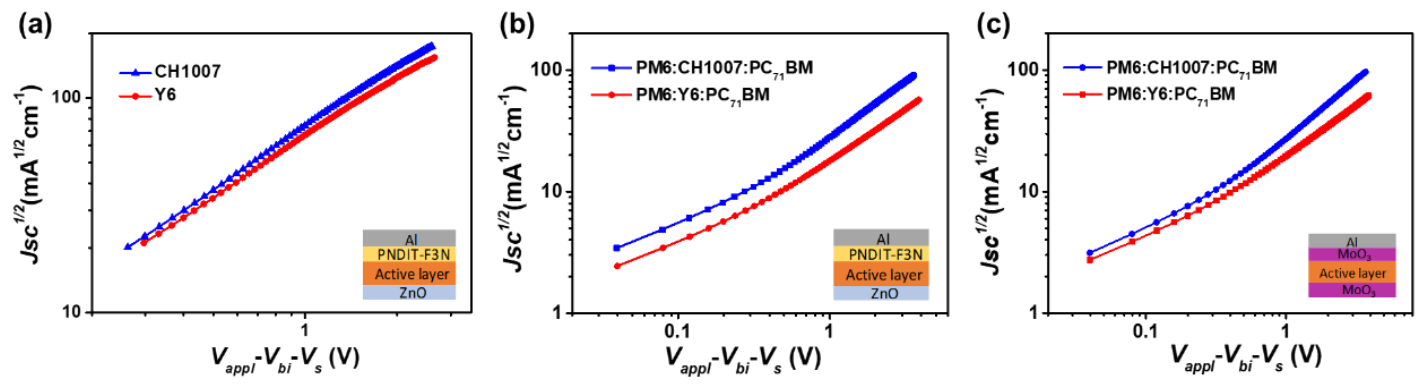

Figure S6. SCLC characteristics of (a) electron-only devices of Y6 and CH1007, and (b) electron- and (c) hole-only devices of PM6:Y6/CH1007:PC 71 BM blends.

Table S5. Summary of photovoltaic and SCLC characteristics of PM6:Y6/CH1007:PC 71 BM.

\begin{tabular}{|c|c|c|c|c|c|c|c|}
\hline & $V_{\text {oc }}(\mathrm{V})$ & $\begin{array}{c}J_{\mathrm{sc}} \\
\left(\mathrm{mA} / \mathrm{cm}^{2}\right)\end{array}$ & FF (\%) & PCE (\%) & $\begin{array}{c}\mu_{\mathrm{h}} \\
\left(\mathrm{cm}^{2} \mathrm{~V}^{-1} \mathrm{~S}^{-1}\right)\end{array}$ & $\begin{array}{c}\mu_{\mathrm{e}} \\
\left(\mathrm{cm}^{2} \mathrm{~V}^{-1} \mathrm{~S}^{-1}\right)\end{array}$ & $\begin{array}{c}\mu_{\mathrm{h}} / \mu \\
\mathrm{e}\end{array}$ \\
\hline $\begin{array}{l}\text { PM6:Y6: } \\
\text { PC }_{71} \mathrm{BM}\end{array}$ & $\begin{array}{c}0.841 \\
(0.84 \pm 0.01)^{a}\end{array}$ & $\begin{array}{l}25.80 / 25.38^{b} \\
(25.53 \pm 0.31)^{a}\end{array}$ & $\begin{array}{c}75.70 \\
(75.51 \pm 0.20)^{a}\end{array}$ & $\begin{array}{c}16.41 \\
(16.19 \pm 0.19)^{a}\end{array}$ & $1.2 \times 10^{-4}$ & $8.2 \times 10^{-5}$ & 1.46 \\
\hline $\begin{array}{c}\text { PM6:CH1oo7: } \\
\text { PC } C_{71} \mathrm{BM}\end{array}$ & $\begin{array}{c}0.822 \\
(0.82 \pm 0.02)^{a}\end{array}$ & $\begin{array}{l}27.48 / 26.74^{b} \\
(27.04 \pm 0.28)^{a}\end{array}$ & $\begin{array}{c}75.61 \\
(75.53 \pm 0.11)^{a}\end{array}$ & $\begin{array}{c}17.08 \\
(16.75 \pm 0.23)^{a}\end{array}$ & $1.8 \times 10^{-4}$ & $1.7 \times 10^{-4}$ & 1.06 \\
\hline
\end{tabular}

${ }^{a}$ The statistics were calculated from 15 devices. ${ }^{b}$ The value was calculated from EQE spectrum.

Table S6. Summary of photovoltaic characteristics of binary PM6:Y6/CH1007.

\begin{tabular}{ccccc}
\hline & $V_{\text {oc }}(\mathrm{V})$ & $\begin{array}{c}J_{\text {sc }} \\
\left(\mathrm{mA} / \mathrm{cm}^{2}\right)\end{array}$ & FF (\%) & PCE (\%) \\
\hline PM6:Y6 & 0.830 & 25.31 & 74.20 & 15.59 \\
& $(0.83 \pm 0.01)^{a}$ & $(24.91 \pm 0.30)^{a}$ & $(73.87 \pm 0.22)^{a}$ & $(15.27 \pm 0.25)^{a}$ \\
PM6:CH1007 & 0.820 & 27.03 & 72.00 & 15.96 \\
& $(0.82 \pm 0.01)^{a}$ & $(26.43 \pm 0.35)^{a}$ & $(72.20 \pm 0.20)^{a}$ & $(15.75 \pm 0.20)^{a}$ \\
\hline
\end{tabular}

${ }^{a}$ The statistics were calculated from 15 devices.
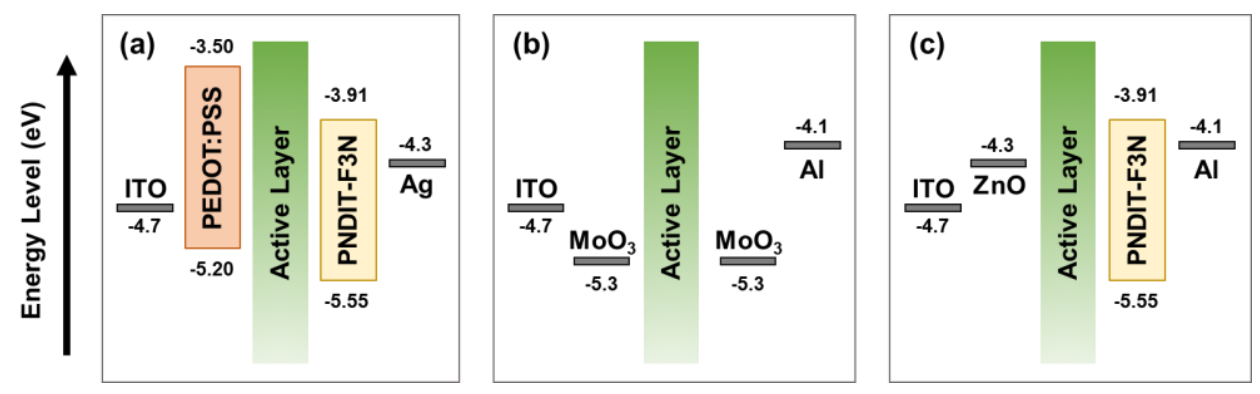

Figure S7. Energy levels of materials used in (a) photovoltaic devices, and (b) hole-only and (c) electron-only SCLC devices. ${ }^{3,10-12}$ 


\section{Light Intensity Dependence Characteristics.}
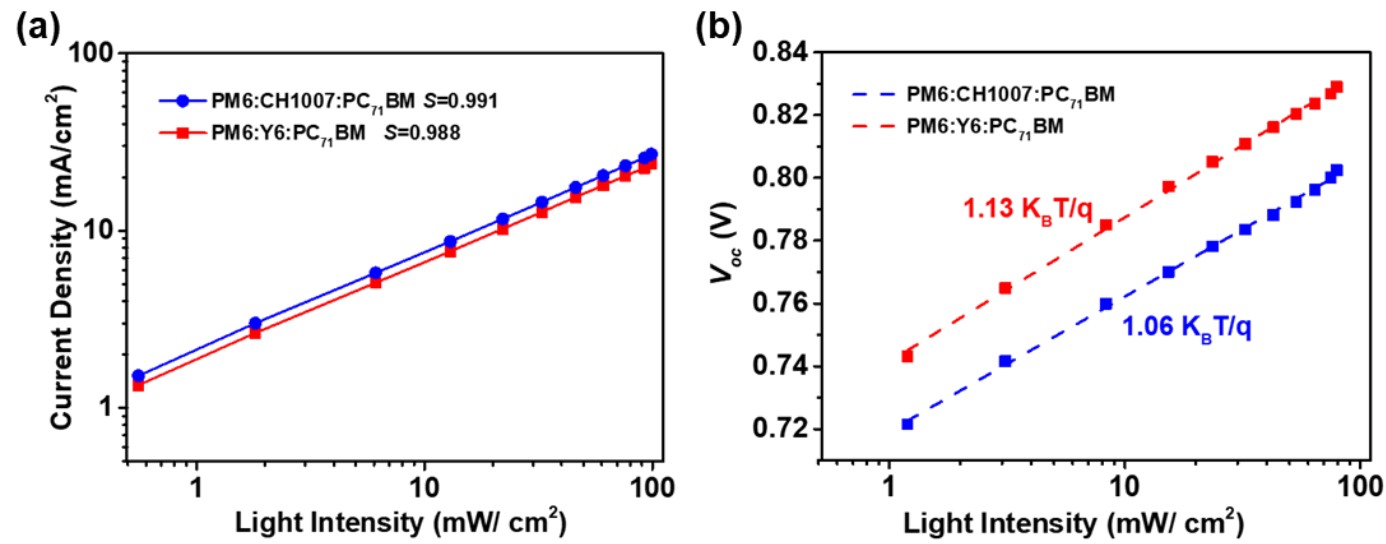

Figure S8. Light-intensity dependent (a) $J_{s c}$ and (b) $V_{o c}$ curves of devices based on PM6:Y6/CH1007:PC 71 BM. 


\section{Atomic Force Microscopy Characteristics.}

Atomic force microscopy measurements were performed on a Scanning Probe Microscope Dimension 3100 in tapping mode. All samples were spin-cast on ITO/PEDOT:PSS substrates.

(a)

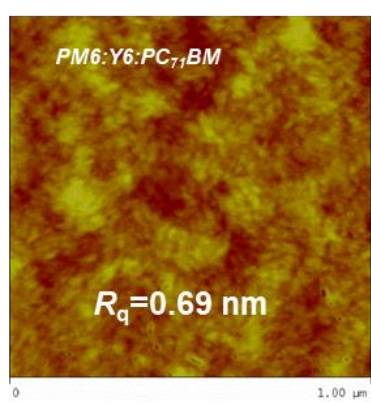

(c)

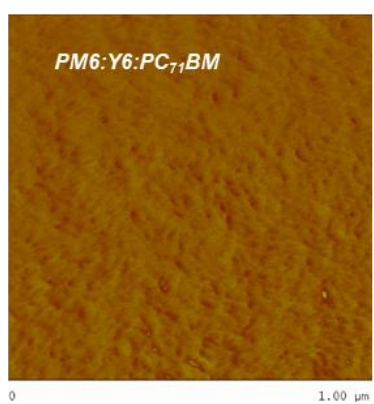

(b)

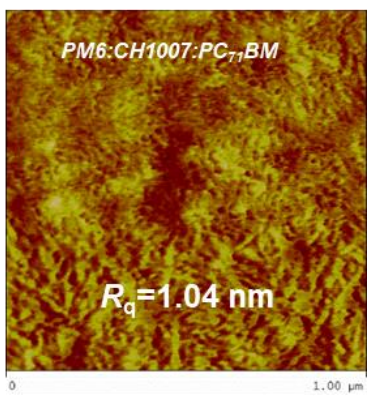

(d)

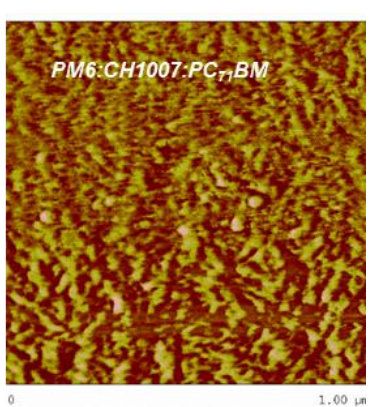

Figure S9. Height images of (a) PM6:Y6: $\mathrm{PC}_{71} \mathrm{BM}$ and (b) PM6:CH1007:PC ${ }_{71} \mathrm{BM}$, and phase images of (c) PM6:Y6:PC ${ }_{71} \mathrm{BM}$ and (d) PM6:CH1007:PC ${ }_{71} \mathrm{BM}$. The scale of the images is $1.00 \mu \mathrm{m}^{2}$. 


\section{${ }^{1} \mathrm{H}$ and ${ }^{13} \mathrm{C}$ NMR Spectra.}
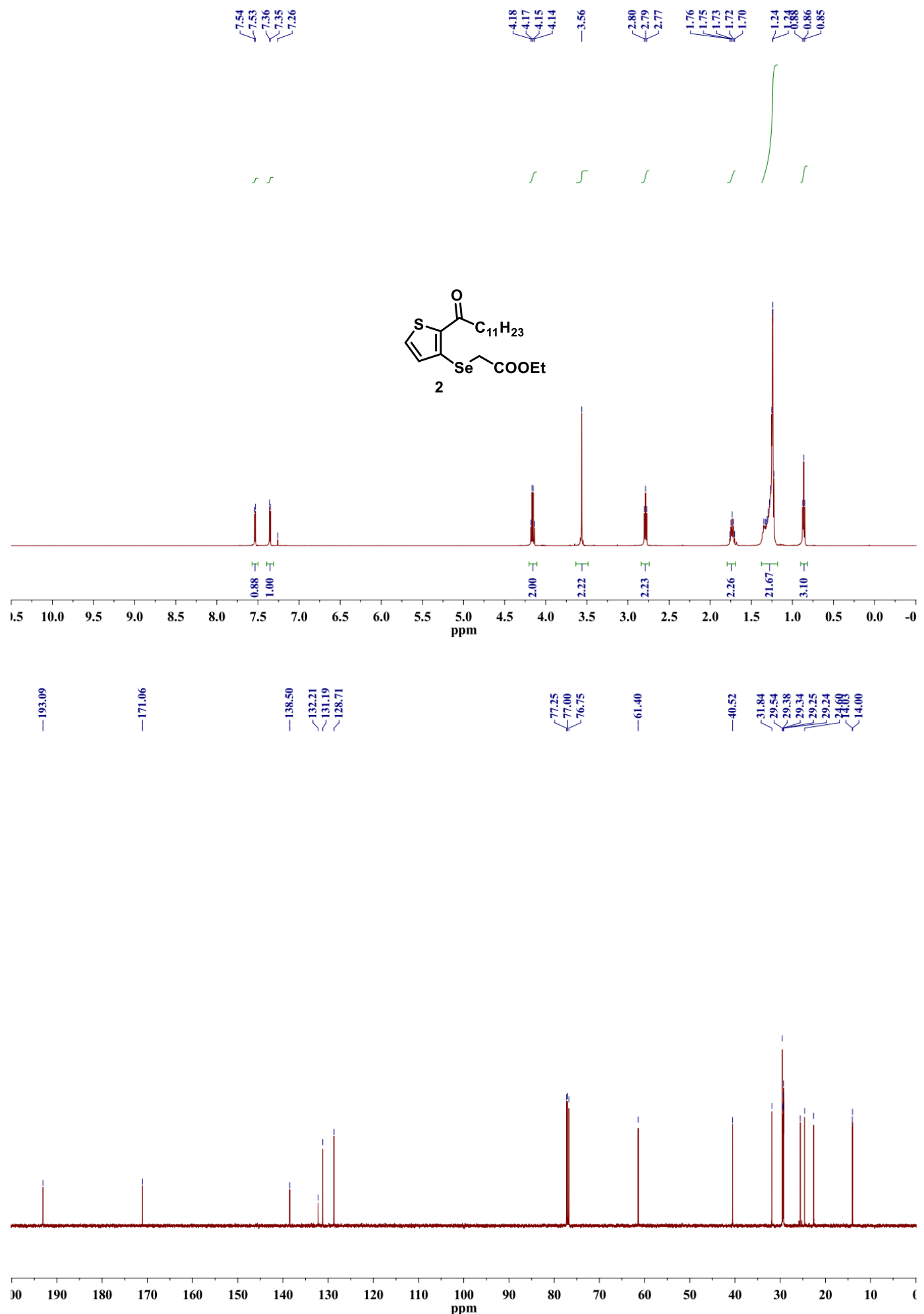

Figure S10. ${ }^{1} \mathrm{H}$ and ${ }^{13} \mathrm{C}$ NMR spectra of compound 2 . 

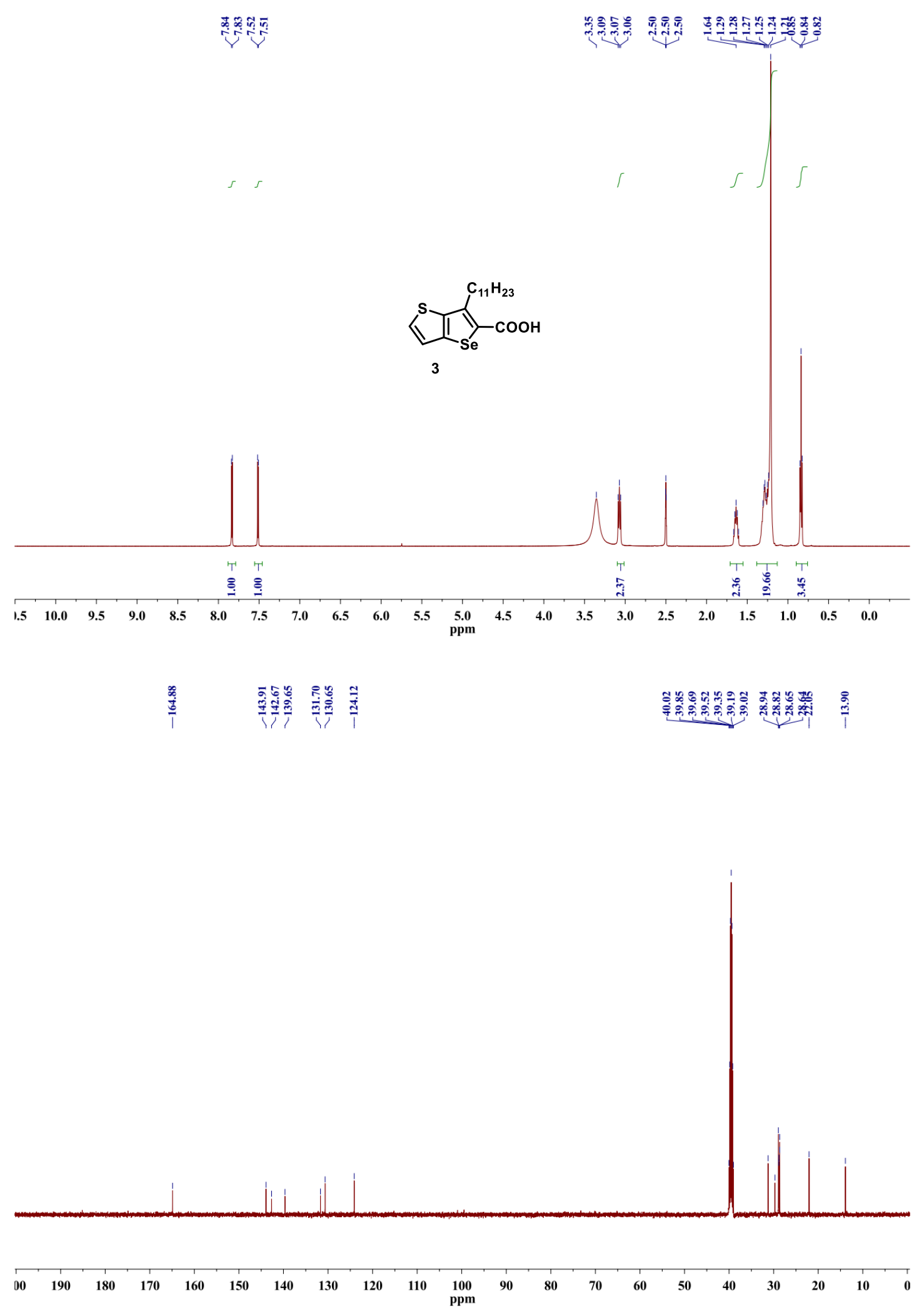

Figure S11. ${ }^{1} \mathrm{H}$ and ${ }^{13} \mathrm{C}$ NMR spectra of compound 3 . 


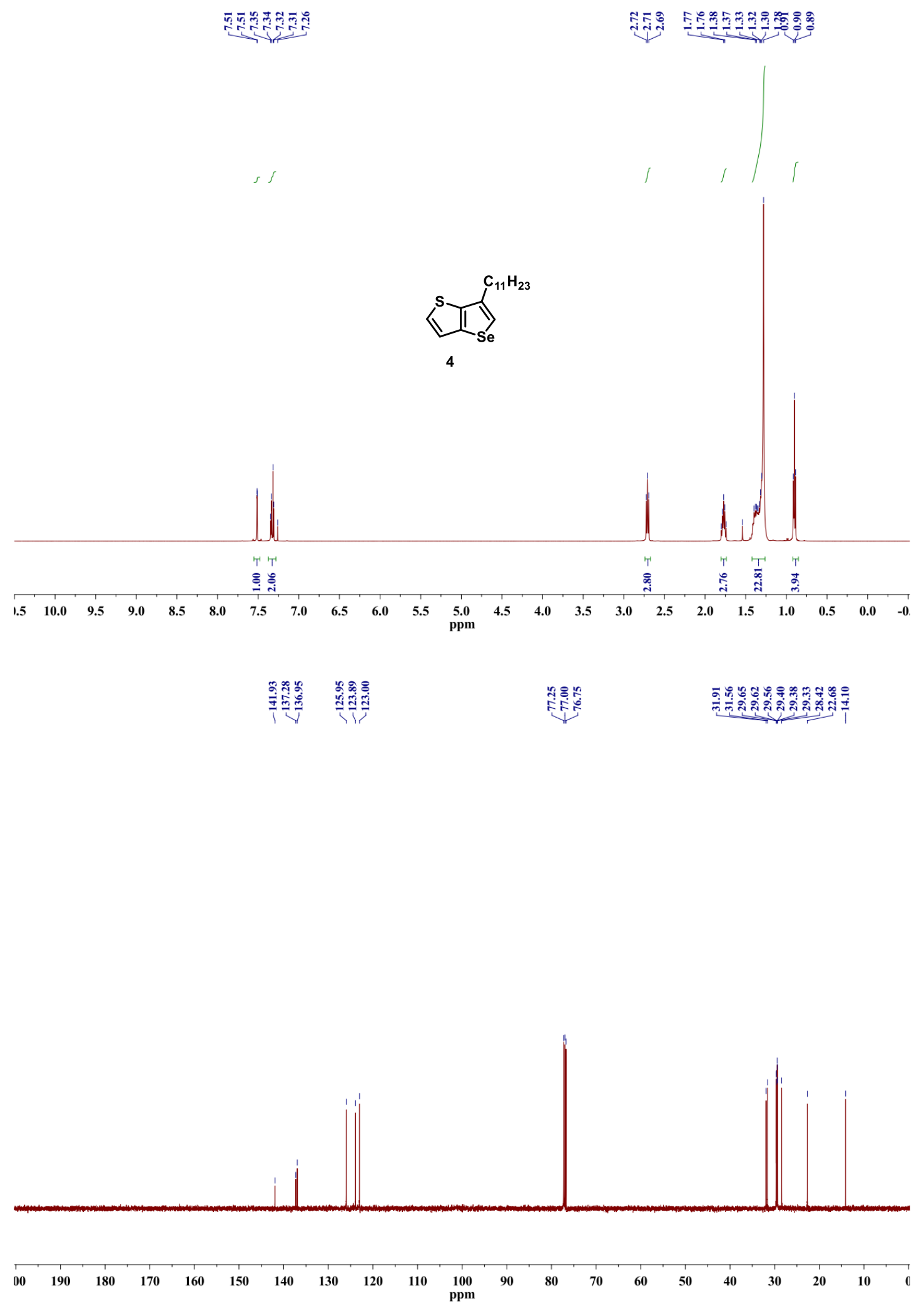

Figure S12. ${ }^{1} \mathrm{H}$ and ${ }^{13} \mathrm{C}$ NMR spectra of compound 4 . 

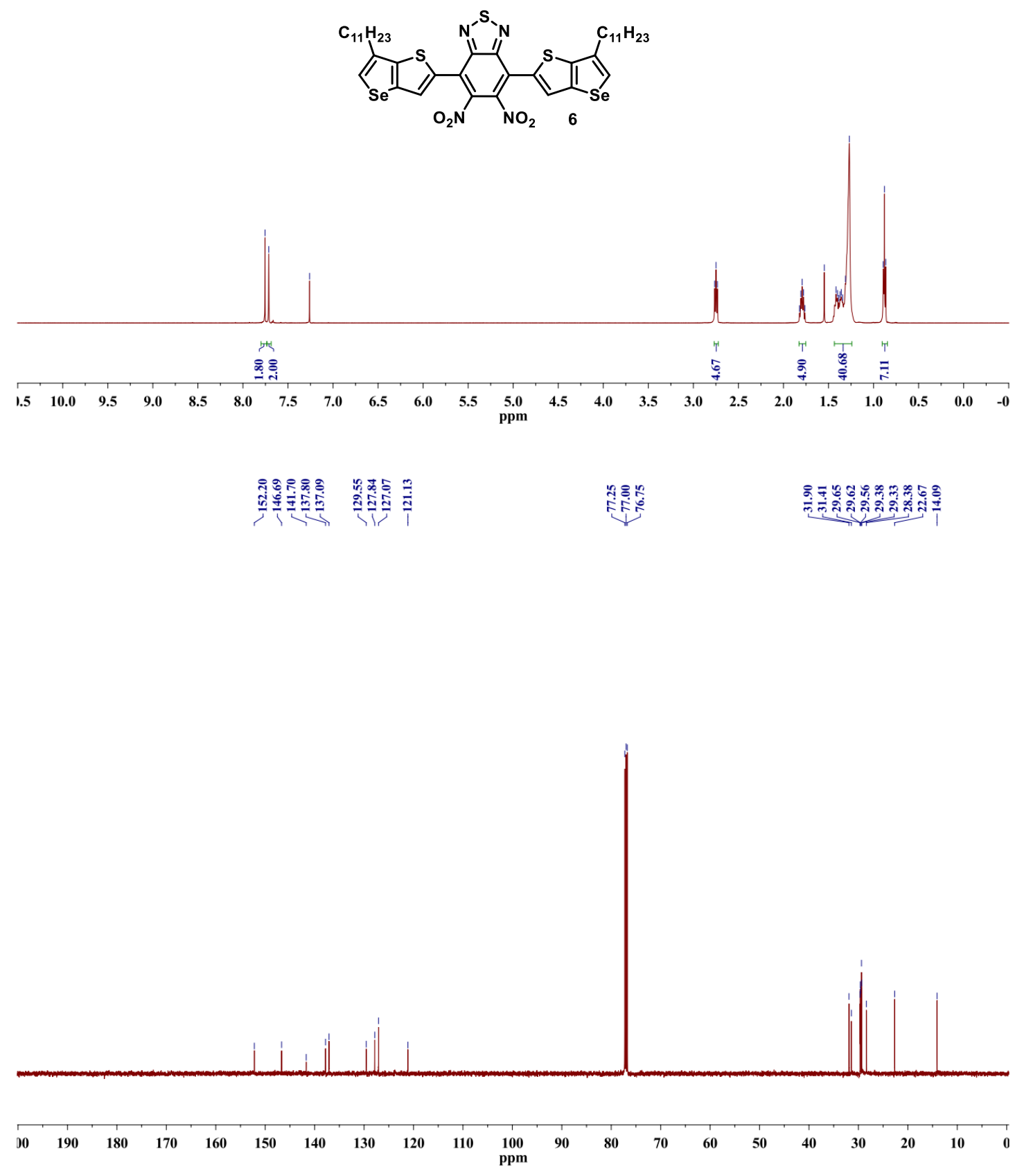

Figure S13. ${ }^{1} \mathrm{H}$ and ${ }^{13} \mathrm{C}$ NMR spectra of compound 6 . 
BOBSP
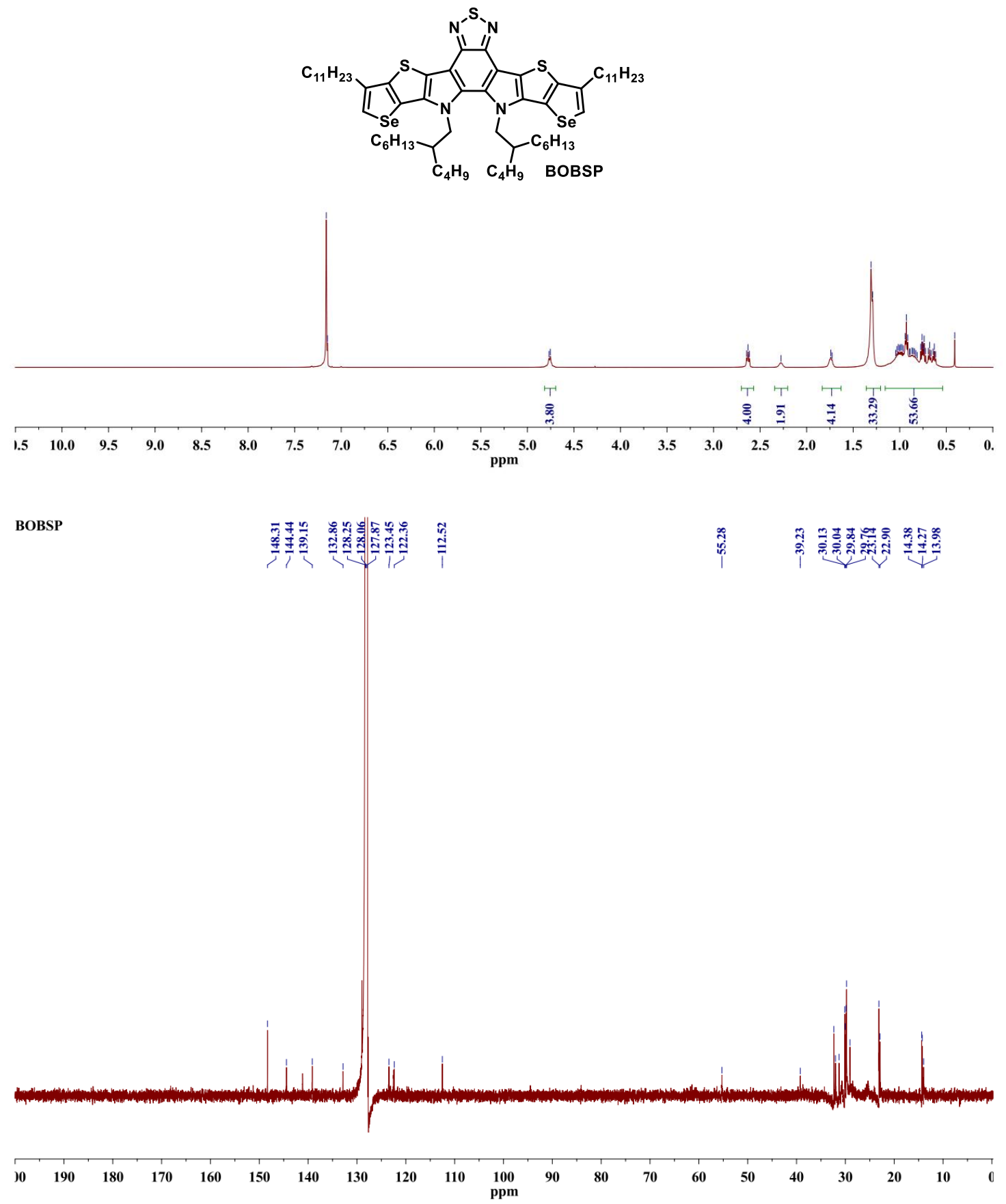

Figure S14. ${ }^{1} \mathrm{H}$ and ${ }^{13} \mathrm{C}$ NMR spectra of BOBSP. 


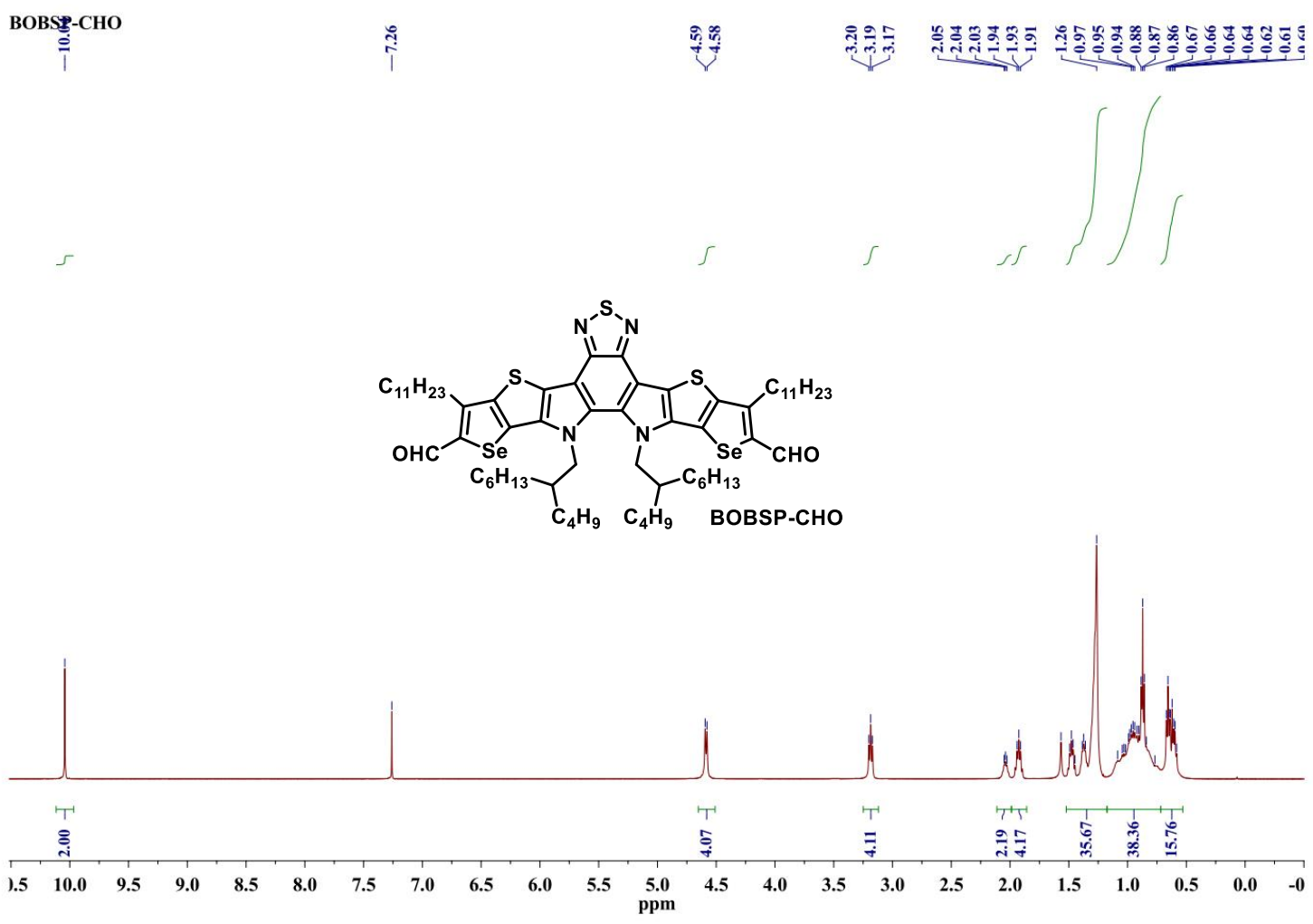

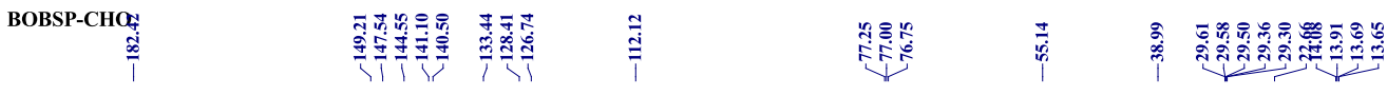

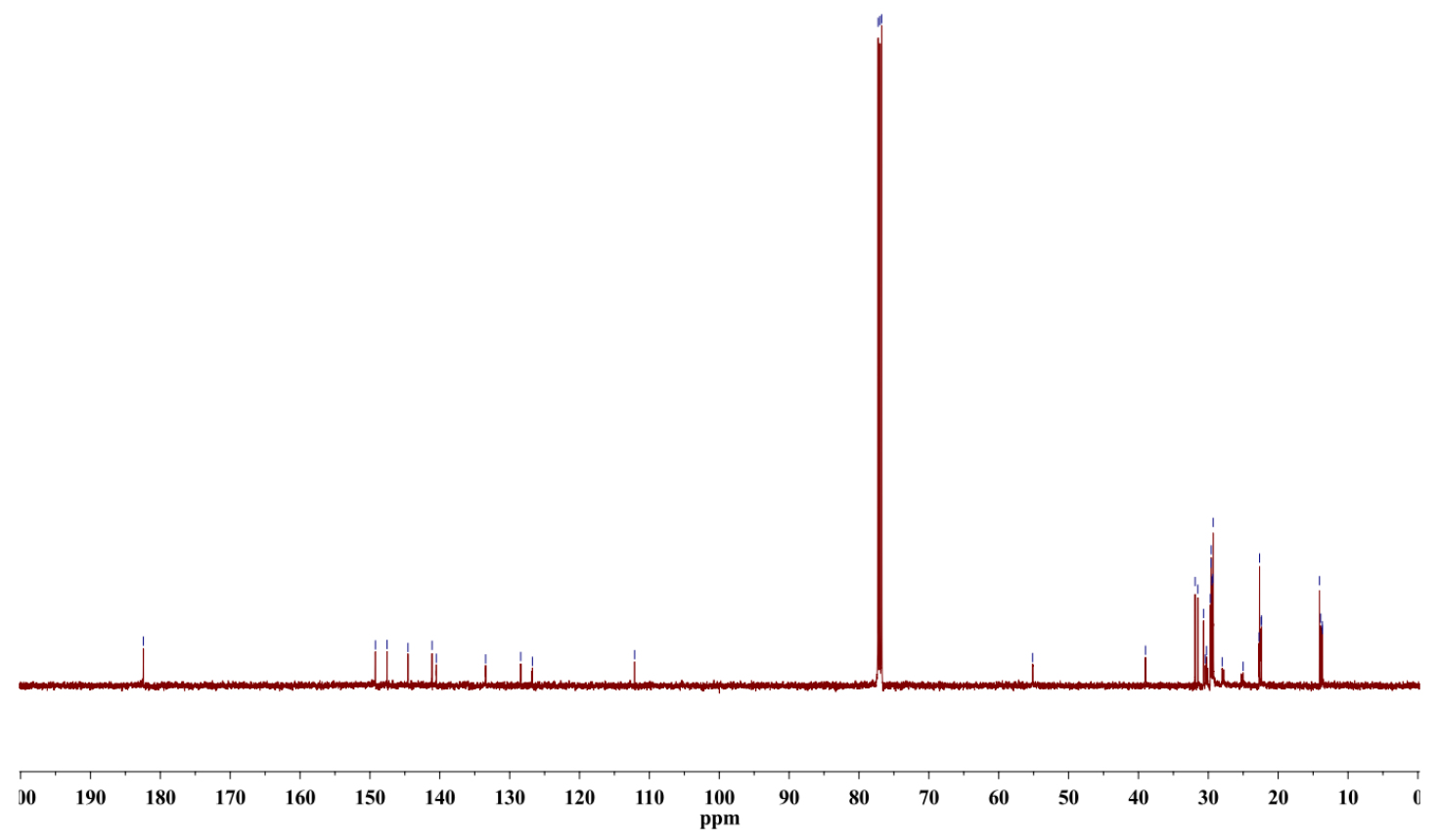

Figure S15. ${ }^{1} \mathrm{H}$ and ${ }^{13} \mathrm{C}$ NMR spectra of BOBSP-CHO. 


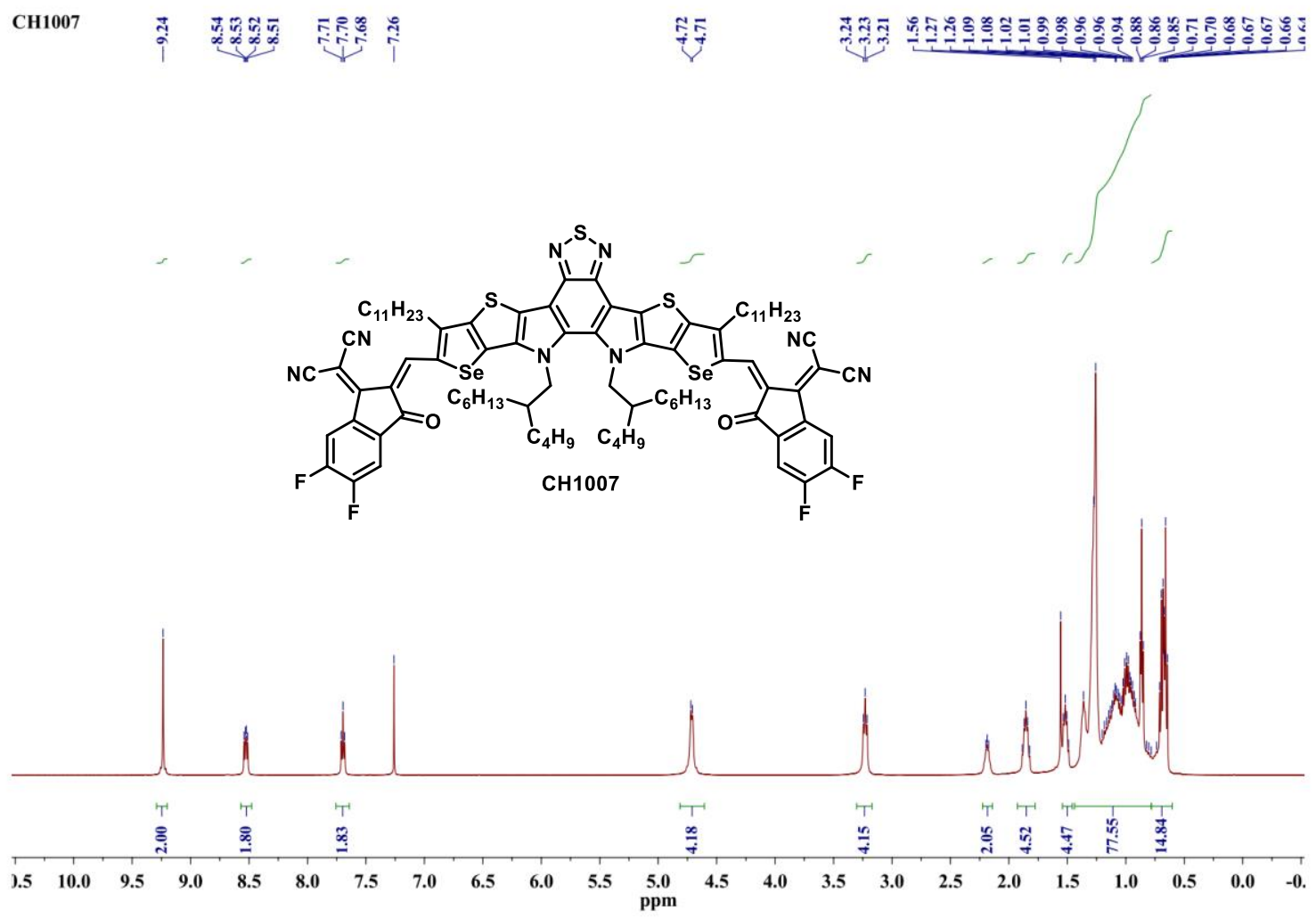

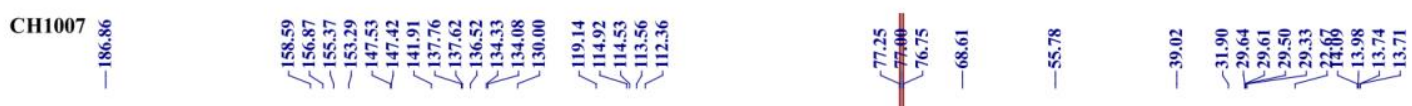

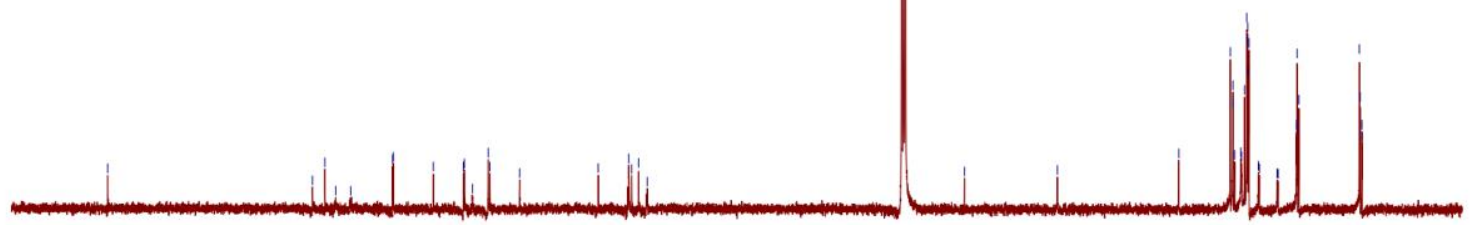

$\begin{array}{lllllllllllllllllllllll}30 & 190 & 180 & 170 & 160 & 150 & 140 & 130 & 120 & 110 & 100 & 90 & 80 & 70 & 60 & 50 & 40 & 30 & 20 & 10 & (\end{array}$

Figure S16. ${ }^{1} \mathrm{H}$ and ${ }^{13} \mathrm{C}$ NMR spectra of $\mathbf{C H 1 0 0 7}$. 


\section{References.}

1. Mishra, S. P.; Javier, A. E.; Zhang, R.; Liu, J.; Belot, J. A.; Osaka, I.; McCullough, R. D., Mixed selenium-sulfur fused ring systems as building blocks for novel polymers used in field effect transistors. J. Mater. Chem. 2011, 21 (5), 1551-1561.

2. Cheng, D.; Knox, K. R.; Cohen, T., Tandem Lithium-Ene Cyclization and Thiophenoxide Expulsion to Produce Fused Vinylcyclopropanes: First Observation of Allylic Lithium Oxyanion-Induced Reactivity and Stereoselectivity in Intramolecular Carbolithiation. J. Am. Chem. Soc. 2000, 122 (2), 412-413.

3. Yuan, J.; Zhang, Y.; Zhou, L.; Zhang, G.; Yip, H.-L.; Lau, T.-K.; Lu, X.; Zhu, C.; Peng, H.; Johnson, P. A.; Leclerc, M.; Cao, Y.; Ulanski, J.; Li, Y.; Zou, Y., Single-Junction Organic Solar Cell with over 15\% Efficiency Using Fused-Ring Acceptor with ElectronDeficient Core. Joule 2019, 3 (4), 1140-1151.

4. Han, G.; Guo, Y.; Song, X.; Wang, Y.; Yi, Y., Terminal $\pi-\pi$ stacking determines three-dimensional molecular packing and isotropic charge transport in an $\mathrm{A}-\pi-\mathrm{A}$ electron acceptor for non-fullerene organic solar cells. J. Mater. Chem. C 2017, 5 (20), 4852-4857.

5. Aldrich, T. J.; Matta, M.; Zhu, W.; Swick, S. M.; Stern, C. L.; Schatz, G. C.; Facchetti, A.; Melkonyan, F. S.; Marks, T. J., Fluorination Effects on Indacenodithienothiophene Acceptor Packing and Electronic Structure, End-Group Redistribution, and Solar Cell Photovoltaic Response. J. Am. Chem. Soc. 2019, 141 (7), 3274-3287.

6. Swick, S. M.; Zhu, W.; Matta, M.; Aldrich, T. J.; Harbuzaru, A.; Lopez Navarrete, J. T.; Ponce Ortiz, R.; Kohlstedt, K. L.; Schatz, G. C.; Facchetti, A.; Melkonyan, F. S.; Marks, T. J., Closely packed, low reorganization energy pi-extended postfullerene acceptors for efficient polymer solar cells. Proc. Natl. Acad. Sci. U. S. A. 2018, 115 (36), E8341-E8348.

7. Shi, X.; Zuo, L.; Jo, S. B.; Gao, K.; Lin, F.; Liu, F.; Jen, A. K. Y., Design of a Highly Crystalline Low-Band Gap Fused-Ring Electron Acceptor for High-Efficiency Solar Cells with Low Energy Loss. Chem. Mater. 2017, 29 (19), 8369-8376.

8. Shi, X.; Liao, X.; Gao, K.; Zuo, L.; Chen, J.; Zhao, J.; Liu, F.; Chen, Y.; Jen, A. K. Y., An Electron Acceptor with Broad Visible-NIR Absorption and Unique Solid State Packing for As-Cast High Performance Binary Organic Solar Cells. Adv. Funct. Mater. 2018, 28 (33), 1802324.

9. Liao, X.; Shi, X.; Zhang, M.; Gao, K.; Zuo, L.; Liu, F.; Chen, Y.; Jen, A. K., Fused selenophene-thieno[3,2-b]thiophene-selenophene (ST)-based narrow-bandgap electron acceptor for efficient organic solar cells with small voltage loss. Chem. Commun. 2019, 55 (57), 8258-8261.

10. Chen, Z.; Hu, Z.; Wu, Z.; Liu, X.; Jin, Y.; Xiao, M.; Huang, F.; Cao, Y., Counterion-tunable n-type conjugated polyelectrolytes for the interface engineering of efficient polymer solar cells. J. Mater. Chem. A 2017, 5 (36), 19447-19455.

11. Jiang, K.; Wei, Q.; Lai, J. Y. L.; Peng, Z.; Kim, H. K.; Yuan, J.; Ye, L.; Ade, H.; Zou, Y.; Yan, H., Alkyl Chain Tuning of Small Molecule Acceptors for Efficient Organic Solar Cells. Joule 2019, 3 (12), 3020-3033.

12. Kokil, A.; Yang, K.; Kumar, J., Techniques for characterization of charge carrier mobility in organic semiconductors. J. Polym. Sci. B Polym. Phys. 2012, 50 (15), 11301144. 